\title{
A mutant allele of $\zeta$-carotene isomerase (Z- ISO) is associated with the yellow pigmentation of the "Pinalate" sweet orange mutant and reveals new insights into its role in fruit carotenogenesis
}

\author{
María J. Rodrigo ${ }^{1 *}$ (D), Joanna Lado ${ }^{1,2}$, Enriqueta Alós ${ }^{1}$, Berta Alquézar ${ }^{1,3}$, Orly Dery ${ }^{4}$, Joseph Hirschberg ${ }^{4}$ and
} Lorenzo Zacarías ${ }^{1}$

\begin{abstract}
Background: Fruit coloration is one of the main quality parameters of Citrus fruit primarily determined by genetic factors. The fruit of ordinary sweet orange (Citrus sinensis) displays a pleasant orange tint due to accumulation of carotenoids, representing $\beta, \beta$-xanthophylls more than $80 \%$ of the total content. 'Pinalate' is a spontaneous bud mutant, or somatic mutation, derived from sweet orange 'Navelate', characterized by yellow fruits due to elevated proportions of upstream carotenes and reduced $\beta, \beta$-xanthophylls, which suggests a biosynthetic blockage at early steps of the carotenoid pathway.

Results: To identify the molecular basis of 'Pinalate' yellow fruit, a complete characterization of carotenoids profile together with transcriptional changes in carotenoid biosynthetic genes were performed in mutant and parental fruits during development and ripening. 'Pinalate' fruit showed a distinctive carotenoid profile at all ripening stages, accumulating phytoene, phytofluene and unusual proportions of 9,15,9'-tri-cis- and 9,9'-di-cis-Z-carotene, while content of downstream carotenoids was significantly decreased. Transcript levels for most of the carotenoid biosynthetic genes showed no alterations in 'Pinalate'; however, the steady-state level mRNA of $\zeta$-carotene isomerase (Z-ISO), which catalyses the conversion of 9,15,9'-tri-cis- to 9,9'-di-cis-Z-carotene, was significantly reduced both in 'Pinalate' fruit and leaf tissues. Isolation of the 'Pinalate' Z-ISO genomic sequence identified a new allele with a single nucleotide insertion at the second exon, which generates an alternative splicing site that alters Z-ISO transcripts encoding non-functional enzyme. Moreover, functional assays of citrus Z-ISO in E.coli showed that light is able to enhance a non-enzymatic isomerization of tri-cis to di-cis-ל-carotene, which is in agreement with the partial rescue of mutant phenotype when 'Pinalate' fruits are highly exposed to light during ripening.

(Continued on next page)
\end{abstract}

\footnotetext{
* Correspondence: mjrodrigo@iata.csic.es

${ }^{1}$ Instituto de Agroquímica y Tecnología de Alimentos (IATA), Consejo

Superior de Investigaciones Científicas (CSIC), Calle Catedrático Agustín

Escardino 7, 46980 Valencia, Spain

Full list of author information is available at the end of the article
}

(C) The Author(s). 2019 Open Access This article is distributed under the terms of the Creative Commons Attribution 4.0 International License (http://creativecommons.org/licenses/by/4.0/), which permits unrestricted use, distribution, and reproduction in any medium, provided you give appropriate credit to the original author(s) and the source, provide a link to the Creative Commons license, and indicate if changes were made. The Creative Commons Public Domain Dedication waiver (http://creativecommons.org/publicdomain/zero/1.0/) applies to the data made available in this article, unless otherwise stated. 


\begin{abstract}
(Continued from previous page)
Conclusion: A single nucleotide insertion has been identified in 'Pinalate' Z-ISO gene that results in truncated proteins. This causes a bottleneck in the carotenoid pathway with an unbalanced content of carotenes upstream to $\beta, \beta$-xanthophylls in fruit tissues. In chloroplastic tissues, the effects of Z-ISO alteration are mainly manifested as a reduction in total carotenoid content. Taken together, our results indicate that the spontaneous single nucleotide insertion in Z-ISO is the molecular basis of the yellow pigmentation in 'Pinalate' sweet orange and points this isomerase as an essential activity for carotenogenesis in citrus fruits.
\end{abstract}

Keywords: Carotenoid, $\zeta-$ Carotene isomerase, Citrus fruit, gene expression, Mutant, Pigmentation, Ripening,

\section{Background}

Citrus fruit is the main category of tree fruit crops in the world, with a total production of 124 MT. Sweet orange (Citrus sinensis), the most cultivated worldwide, accounts for $62 \%$ of the total citrus fruits production (FAOSTAT, 2017). As in many other fruits, the pigmentation of sweet orange is one of the most important quality traits, which is due to the content and composition of carotenoids [1]. Carotenoids constitute a large family of isoprenoid-compounds with more than 1182 different structures $[2,3]$. Carotenoids are synthetized by all photosynthetic organisms in plastids and cover essential roles in the photosystems, as photoprotective molecules, and are the precursors of phytohormones abscisic acid (ABA) and strigolactones, and other signalling molecules [4].

The carotenoid biosynthetic pathway is well established in model plants and agronomic important crops, being tomato the preferred model for carotenogenic studies in fruit [5-7]. In the genus Citrus the high diversity in fruit pigmentation among different species and varieties is based on their specific carotenoid complements [8-10]. In mature fruit of sweet oranges the qualitative carotenoid composition in flavedo and pulp is similar but flavedo contains about 4 to 10 -fold more carotenoids, ranging the total content from 50 to $150 \mathrm{\mu g} \mathrm{g}^{-1}$ fresh weight (FW) in the flavedo and $5-25 \mu \mathrm{g} \mathrm{g}^{-1} \mathrm{FW}$ in the pulp. The carotenoid profile in mature sweet orange fruit tissues displays more than $80 \%$ of the total content of $\beta, \beta$-xanthophylls, being 9-cis-violaxanthin the predominant carotenoid [11-17]. Other $\beta, \beta, x a n-$ thophylls such as antheraxanthin, $\beta$-cryptoxanthin, neoxanthin and zeaxanthin, the carotene phytoene and the C30-apocarotenoid $\beta$-citraurin, are present in variable amounts depending on the fruit tissue and the cultivar [18, 19]. Minor concentrations of phytofluene, $\alpha-, \beta$ - and $\zeta$ carotene, and other xanthophylls have been reported [20].

Changes in carotenoids during fruit ripening of sweet orange are primarily regulated by the transcriptional level of the main structural carotenoid biosynthetic genes (Fig. 1) [8-10, 12, 21, 22]. The flavedo of immature sweet orange shows a carotenoid profile characteristic of chloroplastic-containing tissue being lutein the most abundant carotenoid followed by $\alpha-$ and $\beta$-carotenes, and all-trans- violaxanthin, neoxanthin and zeaxanthin $[8,11,12,23-25]$. At this green or immature stage, the expressions of phytoene synthase (PSY), phytoene desaturase (PDS) and $\zeta$ carotene desaturase $(Z D S)$ genes, involved in the early biosynthetic steps of the pathway (Fig. 1), have been reported to be relatively low $[11,12]$. During the onset of color break the expression of most of the genes involved in the upstream reactions, particularly PSY, is highly up-regulated enhancing the flux of the pathway $[9,11,12,15,21]$.

In plants, the action of two isomerases, $15-$-cis- $\zeta$-carotene isomerase (Z-ISO) [26, 27] and lycopene isomerase (CRTISO) [28], are needed to obtain all-trans-lycopene, the cyclases substrate (Fig. 1). The expression of CRTISO in different Citrus species does not correlate with the $\beta, \beta$-xanthophylls accumulation [12], and the characterization of citrus Z-ISO is restricted to pummelo (Citrus maxima) [29].

The lycopene $\varepsilon$-cyclase gene, $\varepsilon L C Y$, is down-regulated during ripening of sweet orange fruit having a prominent role redirecting the flux of the pathway to the $\beta, \beta$-branch (Fig. 1) [11]. In citrus fruit the cyclization of lycopene to produce $\beta$-carotene is catalyzed by two different enzymes $\beta$-lycopene cyclase ( $\beta \mathrm{LCY}$ ). The $\beta L C Y 1$ displays a constitutive expression in sweet orange fruit tissues during ripening, while $\beta L C Y 2$ is only expressed in chromoplastic tissues and parallels with the accumulation of $\beta, \beta$-xanthophylls $[14,30]$. Subsequently in the pathway, four enzymes have been reported to be involved in $\alpha$ - and $\beta$-carotene hydroxylation in citrus to produce xanthophylls: $\mathrm{CitHYb} /$ BCHX, CitCYP97A, CitCYP97B, and CitCYP97C; however, transcriptional and functional studies suggest that only $\beta \mathrm{CHX}$ plays a relevant role in $\beta, \beta$-xanthophyll biosynthesis in citrus fruits [31].

The last enzyme characterized in the plant carotenoid

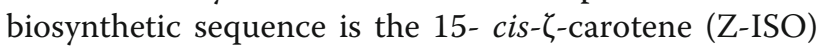
which catalyzes the cis-trans isomerization of central double bond $\left(15-15^{\prime}\right)$ of the 9,15,9'-tri-cis- $\zeta$-carotene, product of PDS, to $9,9^{\prime}$-di-cis- $\zeta$-carotene, substrate to ZDS [26, 27, 32]. The Z-ISO is an integral membrane protein that carries a heme-b cofactor that undergoes redox-dependent ligand switching [27]. The Z-ISO in vivo function was revealed by the identification of 


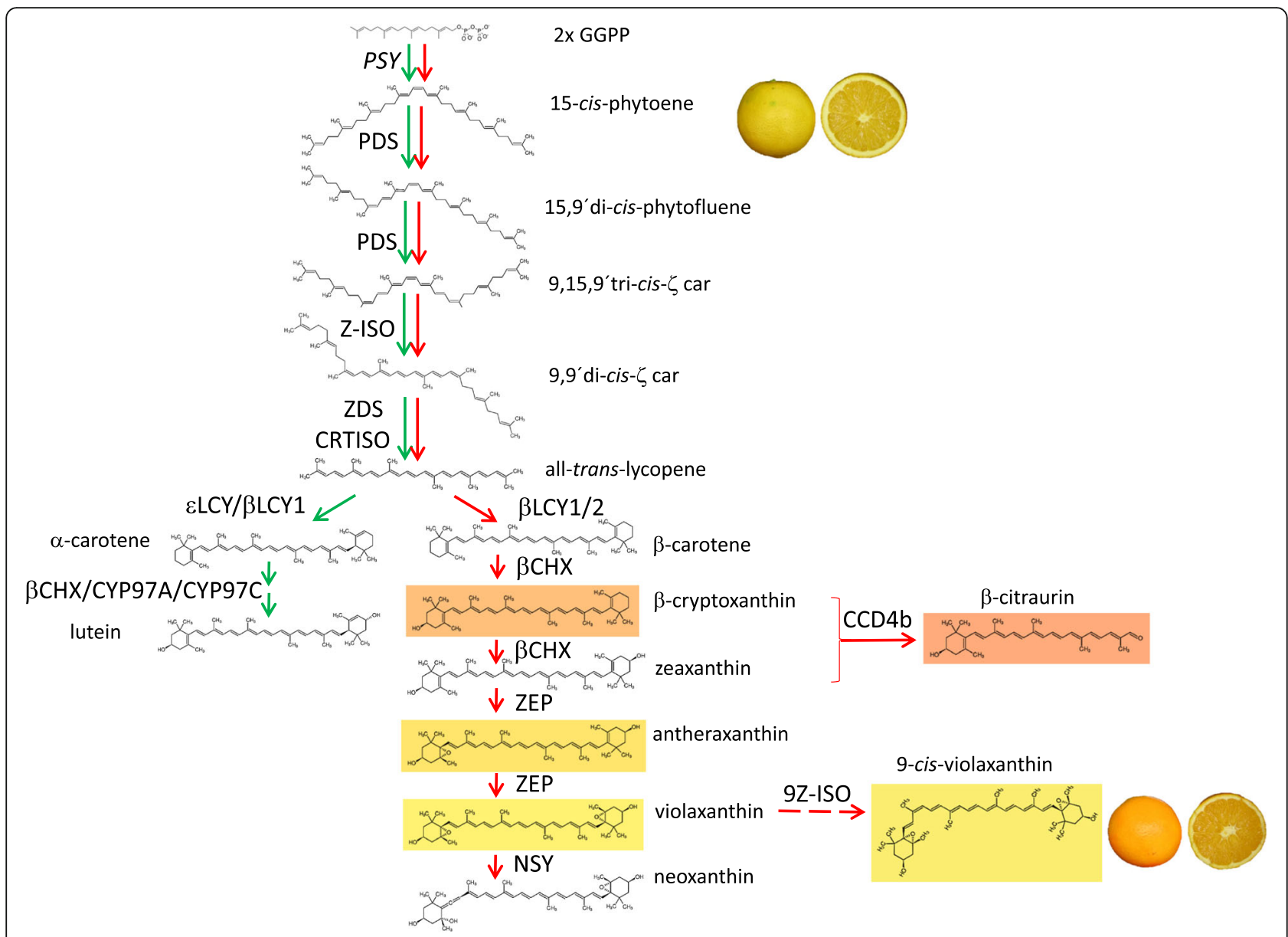

Fig. 1 Schematic representation of carotenoid biosynthetic pathway in sweet orange (Citrus sinensis) fruit indicating main enzymes involved in carotenoid compositional changes during ripening. The predominant flux in immature and full ripe fruit tissues is indicated in green and red arrows, respectively. The discontinuous arrow indicates a enzymatic step not yet characterized. The structure of the main carotenoids involved in sweet orange fruit pigmentation is background colored. Representative pictures of 'Pinalate' sweet orange mutant and its parental genotype 'Navelate' are positioned in the pathway close to the most abundant carotenoid in mature fruit tissues. PSY, phytoene synthase; PDS, phytoene desaturase; Z-ISO, 15-cis-Z-carotene isomerase; ZDS, Z-carotene desaturase; CRTISO, lycopene isomerase; $\beta L C Y 1$, lycopene $\beta$-cyclase 1; $\beta L C Y 2$, chromoplast-specific lycopene $\beta$-cyclase2; $\varepsilon L C Y$, lycopene $\varepsilon$-cyclase; CYP97A and CYP97C, heme-containing cytochrome P450 hydroxylases; $\beta C H X$, non-heme $\beta$-carotene hydroxylase; ZEP, zeaxanthin epoxidase; NSY, neoxanthin synthase; CCD4b, carotenoid cleavage dioxygenase type 4; 9-Z-ISO, 9-Z-violaxanthin isomerase. GGPP, Geranyl geranyl pyrophosphate. Carotenoid structure images were obtained from http://carotenoiddb.jp/ [2]

Arabidopsis $z i c 1$ and maize $y 9$ mutants $[26,32]$ and tomato Z-ISO-VIGS-silenced fruits [33]. All defective ZISO plants showed the characteristic accumulation of 9 , $15,9^{\prime}$-tri-cis- $\zeta$-carotene in addition to a noteworthy increase in phytoene and phytofluene [32, 33]. Interestingly, the function of Z-ISO can be partially compensated by light since $15-15$ 'cis-trans photoisomerization

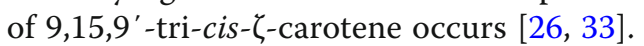

A key strategy to investigate Citrus carotenogenesis is the use of the natural genetic diversity in fruit pigmentation among the large collections of species and spontaneous mutants [16, 34]. The best characterized sweet orange mutants with distinctive fruit coloration are the red-fleshed mutants 'Cara Cara' and 'Hong Anliu'. Both accumulate lycopene in the pulp, a carotene absent in ordinary sweet oranges $[13,16,23]$ and contain unusual elevated amounts of the upstream carotenes phytoene and phytofluene, and reduced levels of downstream $\beta, \beta$ - xanthophylls [13, 23, 35]. Transcriptional and metabolomic studies suggest an alteration in $\beta$ LCY activity in both mutants, either in $\beta L C Y 1$ and/or in the chromoplast-specific $\beta \mathrm{LCY} 2[36,37]$ and in the MEP pathway genes [13].

The sweet orange 'Pinalate' is a spontaneous bud mutant from 'Navelate' genotype with distinctive yellow fruits due to a significant reduction in $\beta, \beta$-xanthophylls [38]. The biochemical data suggest an alteration in 'Pinalate' fruit related to ZDS desaturase or ZDSassociated factors [38, 39]. 'Pinalate'fruits also display reduced levels of the phytohormone ABA, a downstream product of carotenoid metabolism [38]. Due to 
this singularity, 'Pinalate' mutant has been used as experimental tool to investigate the perception and signaling components of ABA in citrus [40] and their role in fruit dehydration and other postharvest disorders [41-44]. Moreover, 'Pinalate' was used to explore the relationship between plastid ultrastructure and carotenoid composition in citrus fruits [39] and to investigate the bioaccessibility of phytoene and phytofluene in orange juice [45]. However, the molecular basis of the 'Pinalate' mutation that causes the partial blockage in the biosynthesis of carotenoids and the yellow phenotype remains elusive and is the main objective of the present work. The comparative analysis of carotenoids and transcriptional profile of main carotenoid biosynthetic genes in fruit and vegetative tissues of 'Pinalate' and its parental 'Navelate' suggested an alteration in the Z-ISO activity. Thus, the isolation of $Z$ ISO gene and itsfunctional characterization from mutant and wild-type showed that 'Pinalate' harbours a mutated Z-ISO allele in heterozygous state that generates non-functional proteins.

\section{Results}

The yellow 'Pinalate' sweet orange mutant shows altered carotenoid profile in fruit tissues during ripening and reduced carotenoid content in leaves

Changes in carotenoid content and composition were evaluated in flavedo and pulp of 'Pinalate' fruits at three ripening stages: immature green, breaker and fully ripe, and compared with those of its wild-type 'Navelate' (Fig. 2). In immature green flavedo the total carotenoid content in 'Pinalate' was about $25 \%$ lower $\left(65 \mu^{-1} \mathrm{~g} \mathrm{~g}^{-1}\right)$ than in parental fruits $\left(85 \mathrm{\mu g} \mathrm{g}^{-1}\right)$ and differences in individual carotenoids were identified. As in parental fruit, the main carotenoid in 'Pinalate' green flavedo was the $\beta, \varepsilon$-xanthophyll lutein $\left(19.5 \mu \mathrm{g} \mathrm{g}^{-1}\right.$ which represents about $\left.30 \%\right)$ containing also $17 \mu \mathrm{g} \mathrm{g}^{-1}$ of $\beta, \beta$-xanthophylls (25\%) (neoxanthin and violaxanthin) as well as $\alpha$ - and $\beta$-carotene $\left(14.3 \mu \mathrm{g} \mathrm{g}^{-1}\right)$. Interestingly, 'Pinalate' green flavedo contained more than $25 \%$ of the upstream carotenes (phytoene, phytofluene and $\zeta$ carotene) which were barely detectable in the parental fruit. In agreement with previous data [46], different $\zeta$-carotene isomers were detected in 'Pinalate' and in the context of

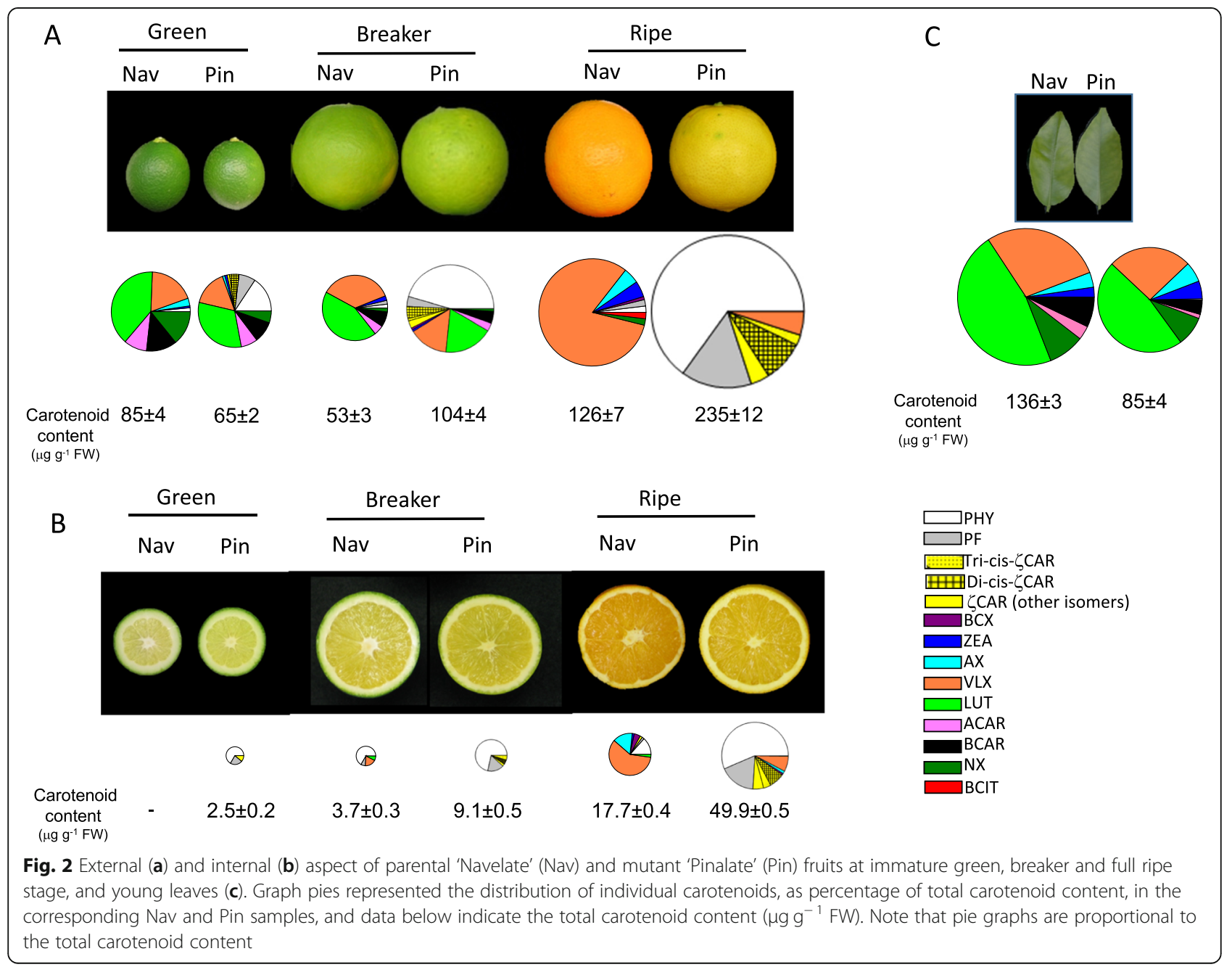


this study it is important to mention that at this green stage the presence of 9,15, 9'tri-cis- $\zeta$-carotene isomer was not detected and the predominant isomer was 9, 9'di-cis- $\zeta$-carotene $\left(2.7 \mu \mathrm{g} \mathrm{g}^{-1}\right)$ (Fig. 2a). At the breaker stage, flavedo of both genotypes exhibited a light green coloration with yellow patches indicative of chlorophylls degradation and the initiation of chloroplasts to chromoplasts transition (Fig. 2a). Flavedo of 'Pinalate' fruit at this stage contained almost double carotenoid content $\left(104 \mu \mathrm{gg}^{-1}\right)$ than those of 'Navelate' $\left(53 \mu \mathrm{gg}^{-1}\right)$, and while in 'Pinalate' this amount involved an $80 \%$ increment over immature green fruits, contrastingly in 'Navelate' represented a $40 \%$ reduction. The carotenoid composition in the peel of both genotypes was different at breaker stage. In wild-type the profile was similar to green fruit but an increase in the proportion of $\beta$, $\beta$-xanthophylls was already evident, indicating the enhancement of carotenogenesis associated with fruit ripening. In 'Pinalate' the content of phytoene $\left(46.8 \mu \mathrm{gg}^{-1}\right)$ and of $\zeta$ carotene $\left(9.4 \mathrm{\mu g} \mathrm{g}^{-1}\right)$ was increased by 3-fold compared to green flavedo and, more importantly, the presence of 9,15, 9'tri-cis- $\zeta$-carotene was detected $\left(1.2 \mu \mathrm{g} \mathrm{g}^{-1}\right)$. At ripe stage, total carotenoid content in the flavedo of 'Pinalate' almost doubled that of the wild-type (235 and $126 \mu \mathrm{g} \mathrm{g}^{-1}$, respectively) and the composition was strikingly different. The flavedo of 'Navelate' contained more than $90 \%$ of $\beta, \beta-$ xanthophylls, with $105.1 \mu \mathrm{g} \mathrm{g}^{-1}$ of violaxanthin and $14.7 \mu \mathrm{g}$ $\mathrm{g}^{-1}$ of other $\beta, \beta$-xanthophylls (zeaxanthin, anteraxanthin and $\beta$-cryptoxanthin), while upstream carotenes, including phytoene and phytofluene, accounted for $5.2 \mu \mathrm{g} \mathrm{g}^{-1}$ and $\zeta$ carotene was not detected. In 'Pinalate', phytoene and phytofluene were overrepresented with concentrations of 153 and $36 \mu \mathrm{g} \mathrm{g}^{-1}$, respectively, and several isomers of both carotenes were identified. Six different isomers were detected for $\zeta$-carotene (Additional file 1: Figure S1), with concentrations of 5.1 and $20.3 \mu \mathrm{g} \mathrm{g}^{-1}$ for 9,15,9'tri-cis and 9,9'di-cis,

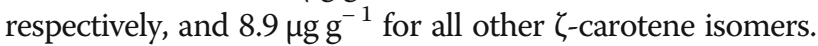
Violaxanthin was the only xanthophyll identified in the flavedo of 'Pinalate' and its concentration was $11.8 \mu \mathrm{g} \mathrm{g}^{-1}$ which is approximately 10 -fold lower than in 'Navelate'.

In the pulp of both genotypes, significant differences in carotenoid content and composition were obvious since green immature stage (Fig. 2b). Carotenoids concentration in the pulp of green 'Navelate' fruit was negligible while in 'Pinalate' minor amounts of phytoene $\left(1.8 \mu \mathrm{gg}^{-1}\right)$, phytofluene $\left(0.4 \mu \mathrm{gg}^{-1}\right)$ and $\zeta$-carotene $\left(0.3 \mathrm{\mu g} \mathrm{g}^{-1}\right)$ were detected. At breaker stage, 'Navelate' pulp displayed low concentration of carotenoids being phytoene the main carotene $\left(2.6 \mu \mathrm{gg}^{-1}\right)$ but also contained a significant proportion of $\beta, \beta$-xanthophylls $\left(0.8 \mu \mathrm{g} \mathrm{g}^{-1}\right)$, particularly violaxanthin and anteraxanthin. In 'Pinalate' there was almost a 4-fold increase in the total carotenoid content compared to green stage with a carotenoid profile similar to green stage. Carotenoid content in the pulp of mature 'Navelate' fruit was 5-fold higher than at breaker, and was predominantly composed by $\beta, \beta$-xanthophylls $\left(13.3 \mu \mathrm{gg}^{-1}\right)$ but also phytoene $\left(3.5 \mu \mathrm{g} \mathrm{g}^{-1}\right)$, phytofluene $\left(0.5 \mu \mathrm{g} \mathrm{g}^{-1}\right)$, and traces of 9,9'di-cis- $\zeta$-carotene and $\beta$-carotene. In ripe 'Pinalate' pulp the concentration of total carotenes increased by 5 fold compared to breaker stage and it was almost 3-fold higher than in 'Navelate'. Phytoene was the predominant carotenoid $\left(27.7 \mu \mathrm{g} \mathrm{g}^{-1}\right)$ representing more than $50 \%$ of the total content, followed by phytofluene $\left(8.7 \mu \mathrm{g} \mathrm{g}^{-1}\right)$ and $\zeta$-carotene $\left(3.7 \mu \mathrm{gg}^{-1}\right.$ of $9,9^{\prime} \mathrm{di}$-cis isomer and 1.8 $\mu \mathrm{g} \mathrm{g}^{-1}$ of $9,15,9^{\prime}$ tri-cis). The concentration of $\beta, \beta$-xan-

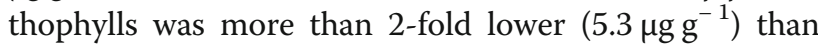
in 'Navelate' with a major proportion of violaxanthin. Representative chromatograms illustrating the marked differences in carotenoid profile between the pulp of 'Pinalate' and Navalete ripe fruits are shown in Additional file 2: Figure S2.

The carotenoid composition in young leaves of both genotypes was very similar and typical of chloroplastic tissues, with a predominance of lutein and other $\beta, \beta$-xanthophylls (violaxanthin, neoxanthin, zeaxanthin) and $\alpha$ - and $\beta$-carotene (Fig. 2c). However, the carotenoid content was $40 \%$ lower in 'Pinalate' leaves compared to parental and, in contrast with fruit tissues, there was no accumulation of upstream carotenes. The chlorophyll content was also reduced by half in mutant leaves $\left(545 \mathrm{\mu g} \mathrm{g}^{-1}\right)$ compared to the parental ones $\left(1146 \mu \mathrm{g} \mathrm{g}^{-1}\right)$.

In the context of this study, it is relevant to mention that neither lycopene nor neurosporene were detected in either mutant and wild-type fruit or leaf extracts.

\section{Light growing conditions affect carotenoid profile of 'Pinalate' fruit peel}

The abnormal accumulation of colorless carotenes and $\zeta$-carotene isomers in 'Pinalate' fruit tissues suggests a partial blockage either in ZDS or Z-ISO activity. It has been reported that Z-ISO activity, but not ZDS, can be partially compensated by light, and under dark growing conditions the biochemical blockage may be intensified [33]. In order to investigate the effect of light/dark conditions on 'Pinalate' carotenoids profiling, we covered 'Pinalate' fruits with black plastic at immature green stage and allowed them to develop and ripe under darkness until harvest [46]. As control, 'Pinalate' fruits directly exposed to sunlight from the external tree canopy were selected. Light and dark-grown fruits were harvested at the ripe stage and the carotenoid profile was determined in the flavedo. At harvest, the external color of the fruits grown under both conditions was different: light-grown fruit displayed a pale-orange coloration while dark-grown fruits where completely light-yellow with any signals of orange tint (Fig. 3). Total carotenoid content was higher in dark-grown $\left(227 \mu \mathrm{g} \mathrm{g}^{-1}\right)$ than in light-exposed fruit $\left(195 \mu \mathrm{gg}^{-1}\right)$ and differences in 
carotenoid profile were also observed. Dark-grown 'Pinalate' flavedo contained a larger proportion ( $84 \%$ of the total carotenoids) and content of phytoene and phytofluene $\left(191 \mu \mathrm{g} \mathrm{g}^{-1}\right)$, and reduced xanthophylls $\left(2.2 \mu \mathrm{g} \mathrm{g}^{-1}\right.$ accounting for $0.97 \%$ of the total) compared to lightgrown which contained $74 \%$ of colorless carotenes $\left(143 \mu \mathrm{gg}^{-1}\right)$ and $16 \%$ of $\beta, \beta$-xanthophylls $\left(33 \mu \mathrm{gg}^{-1}\right)$ (Fig. 3). Interestingly, the content and the ratio of 9 , 15,9'tri-cis:9,9'di-cis $\zeta$-carotene isomers was also affected by light conditions. Thus, whereas in light-grown fruits the ratio tri-cis:di-cis was 0.17 in dark-grown increased up to 0.34 . Moreover, the concentration of tri-cis was 3-fold higher in the flavedo of dark-grown compared to that of light-exposed fruits.

\section{Transcriptional profiles of main carotenoid biosynthetic genes in 'Pinalate' do not correlate with its carotenoid composition}

Since carotenoid composition in 'Pinalate' fruit suggests an impairment in the pathway flux toward the $\beta, \beta$-xanthophylls production, we performed a comparative transcriptional analysis of main genes involved in their synthesis: PSY, PDS, ZDS1, ZDS2 and ZDS3, $\beta L C Y 1$ and $\beta L C Y 2$, and $\beta C H X$, in flavedo, pulp and leaves of mutant and wild-type (Fig. 4). In both genotypes PSY, ZDS1, $\beta L C Y 2$ and $\beta C H X$ genes were upregulated in flavedo and pulp during ripening while PDS gene was almost constitutively expressed in pulp. The expression of $P D S$ in flavedo, and $Z D S 2, Z D S 3$ and $\beta L C Y 1$ in both fruit tissues, did not show clear trends or were constitutive (Fig. $4 \mathrm{a}, \mathrm{b})$. In general, the pattern and relative expression level for most of the genes was similar in 'Pinalate' and 'Navelate', and only some genes showed differences between genotypes: PSY, $\beta L C Y 2$ and $\beta C H X$ transcript levels were significantly lower in flavedo of mature 'Pinalate' fruits, and expression of $\beta C H X$ (breaker stage) and $Z D S 2$ (ripe stage) were higher in 'Pinalate'. The relative transcript level of additional genes such as PSY2 [9], CRTISO, CYP97A and ZEP were also determined in 'Pinalate' and 'Navelate' flavedo at breaker stage and no significant differences between both genotypes were detected (data not shown). In the pulp, the only difference between 'Pinalate' and 'Navelate' gene transcript levels was the reduced expression of ZDS3 in 'Pinalate' green fruits. Altogether, variations in the transcript levels between 'Pinalate' and 'Navelate' fruit tissues do not explain by themselves the differences in carotenoid composition between both genotypes.

Since young leaves of 'Pinalate' and 'Navelate' did not show differences in carotenoid profile but content was reduced by half in the mutant, we also analysed the relative expression levels of carotenoid biosynthetic genes (Fig. 4c). The expression of $P S Y$ and $\beta L C Y 1$ was approximately $50 \%$ lower in 'Pinalate' but other genes showed similar transcript levels in both genotypes (Fig. 4c). No expression of $Z D S 3$ and $\beta L C Y 2$ genes was detected in leaves samples.

\section{'Pinalate' sweet orange mutant harbours a new Z-ISO} allele with a single nucleotide insertion

The massive accumulation of early carotenes in 'Pinalate' fruit tissues together with the abnormal presence of 9,15, 9'tri-cis-ร-carotene without evident correlation with transcriptional profile of main carotenoid biosynthetic genes, and the partial rescue of flavedo wild-type phenotype when mutant fruits were exposed to light, strongly suggest a deficiency in the 15-cis- $\zeta$-carotene isomerase, Z-ISO. In order to explore this hypothesis we identified the sweet orange $Z$ -

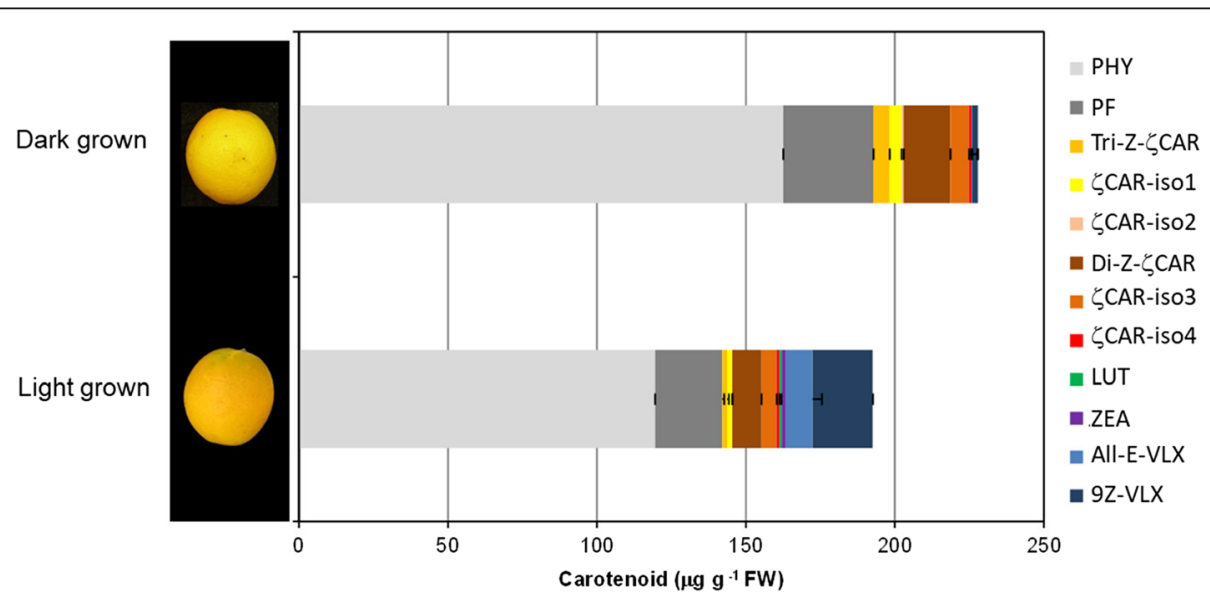

Fig. 3 Effect of light intensity and dark growing conditions on carotenoid content and composition in peel of 'Pinalate' mutant fruit. 'Pinalate' fruits grown in dark conditions were covered at immature green stage with black plastic bags (bottom-end open) and harvested in full ripe stage. Light exposed fruits were harvested at full ripe stage from the South oriented side of the canopy tree to maximize the effect of light exposure 


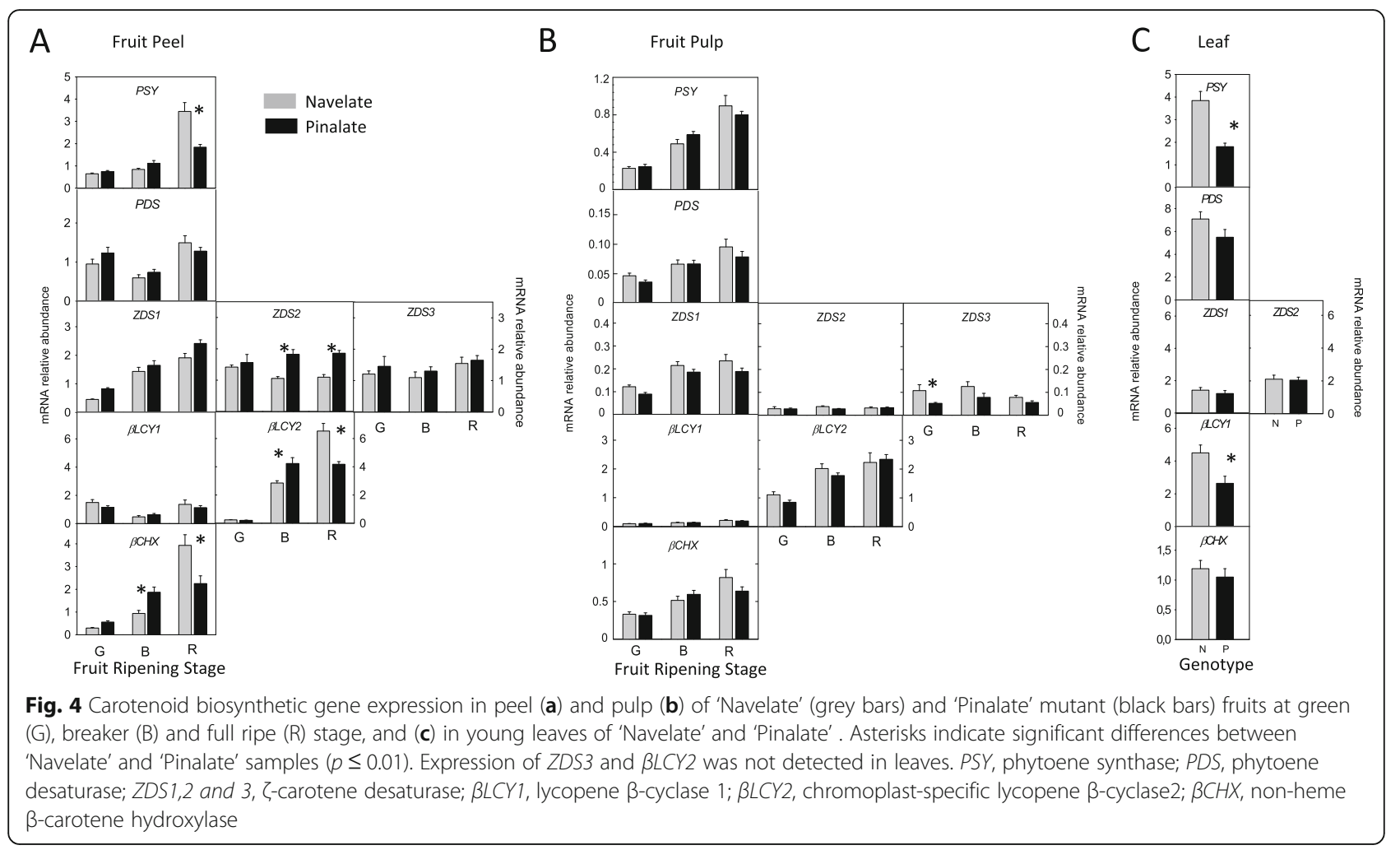

ISO gene by BLAST search in the Citrus sinensis v1.1 genome assembly in Plant Comparative Genomics portal Phytozome (https://phytozome.jgi.doe.gov/) using the Z-ISO from Arabidopsis (NP563879.1). A single gene was identified (orange1.1g017272m.g) with a length of 3189 nucleotides and similar genomic structure to Arabidopsis and maize homologues [26] (Fig. 5a). Sweet orange Z-ISO gene contains four exons and three introns encoding a predicted protein of 374 amino acids. The alignment of orange Z-ISO protein with homologues from Arabidopsis, maize and tomato showed a high degree of identity $(76-71 \%$ at protein level) and most of the variability was detected at the $\mathrm{N}$ terminus which corresponds with the plastid transit peptide predicted by ChloroP1.1 (Fig. 5b). A model prediction of $3 \mathrm{D}$ structure of the sweet orange ZISO was generated in the PPMserver by using I-TASSER [47]. For modelling, two oxidoreductases: the integral membrane sterol reductase from Methylomicrobium alcaliphilum (Acc. PBD: 4QUV) and phenol hydroxylase-Regulatory Protein Complex from Pseudomonas (Acc. PBD: 2INP) were used [27]. The topology of sweet orange Z-ISO was also investigated by using MEMSAT3 [48]. The 3D model and topology analysis for orange Z-ISO showed a structure with seven transmembrane $\alpha$-helices (S1 to S7) (Fig. 5c) suggesting that is an integral membrane protein as reported for maize Z-ISO [27]. The mechanistic study of maize Z-ISO showed that H150 (transmembrane domain 2) and, C263 and H266 (transmembrane domain 5) are critical residues for isomerization involved in the cofactor (heme) binding and reversible heme ligation. In sweet orange Z-ISO homologous residues were identified in transmembrane domains S2 (H158) and S5 (C271 and H274) (Fig. 5b).

Genomic sequencing of Z-ISO from wild-type 'Navelate' revealed a unique sequence for all clones isolated and identical to orange1.1g017272m.g available at the Citrus sinensis genome. By contrast, in 'Pinalate' mutant two different genomic sequences were isolated, one identical to wild-type and a second allele with a $\mathrm{T}$ insertion in the exon 2 at position 1588 (accession number MN417949) (Fig. 6a). Recently, it is has been reported that Z-ISO is a single copy gene in citrus [49] which is also compatible with information obtained from Citrus sinensis genome database; therefore, the presence of two different alleles indicates heterozygosity at Z-ISO locus in 'Pinalate'.

The cDNA sequencing of Z-ISO from parental 'Navelate' sweet orange showed a single sequence with an ORF of 1125 nucleotides (Fig. 6b). PCR amplification of full-length Z-ISO cDNAs from 'Pinalate' samples (flavedo and pulp tissues at breaker and ripe stages) revealed the presence of three $Z$-ISO transcript variants in the mutant (Fig. 6b). Out of 71 independent cDNA clones from 'Pinalate', 36 corresponded to wild-type sequence (WT), 29 were identical to wild-type plus a nucleotide insertion $(\mathrm{T})$ in exon 2 at position 1587_1588 (P6), and 6 sequences (P5) showed a deletion of the first 
A

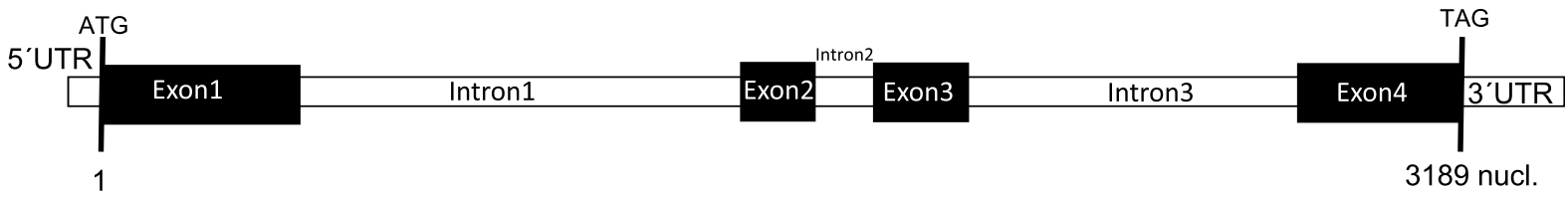

B

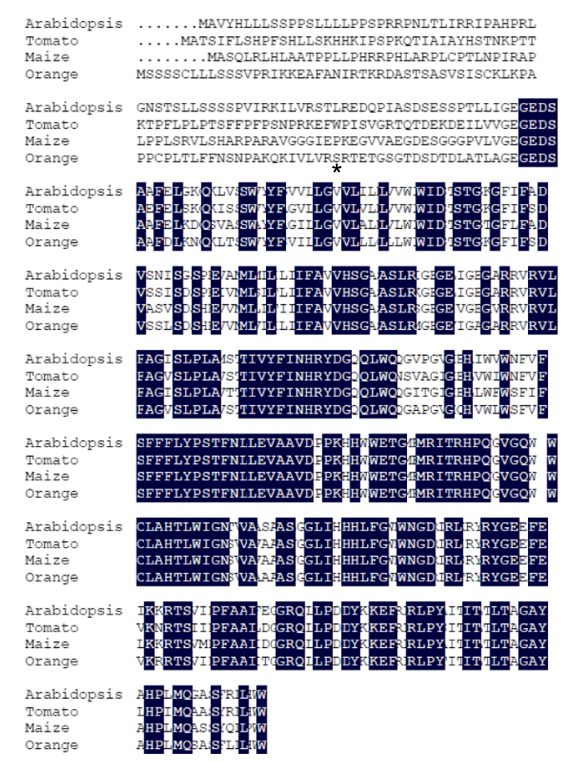

C
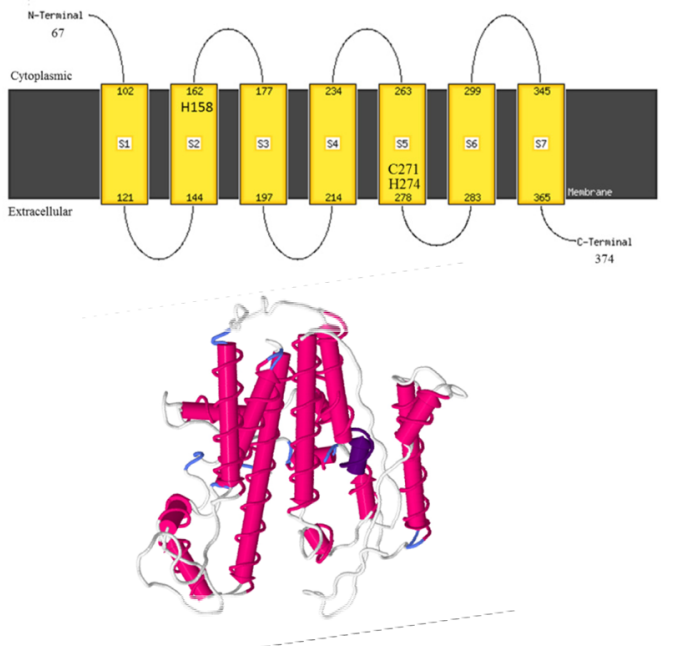

Fig. 5 Sweet orange Z-ISO gene and protein structures. a Structure of sweet orange Z-ISO gene with four exons (black) and three introns (white). b Alignment of Z-ISO proteins from sweet orange (KDO50569.1), Arabidopsis (NP563879.1), maize (NP_001132720.1) and tomato

(XP_004252966.1). Numbers on the left denote the number of amino acid residues and identical for all sequences in a given position are in black background. The end of predicted a plastid transit peptide marked with an asterisk. c Sweet orange Z-ISO topology predicted by MEMSAT3 and tridimensional modelling of Z-ISO (PPMserver) by using iTASSER. Transmembrane a-helix S1 to S7 are represented in yellow and pink in the 2D and 3D-models, respectively

42 nucleotides of exon 2 (positions 1543-1585) in addition to the $\mathrm{T}$ insertion identified in $P 6$ (Fig. 6a,b). Thus, approximately $50 \%$ of the 'Pinalate' Z-ISO transcripts showed an altered sequence (Fig. $6 \mathrm{~b}$ ): the $P 5$ resulted in a shorter sequence (1082 nucleotides) and P6 contained one extra nucleotide compared to the wildtype. Both P5 and P6 give frameshift mutations with premature stop codons at 523 and 487 nucleotides and truncated proteins with 177 and 163 amino acids, respectively (Fig. 6b). The 42 nucleotides deletion in P5 transcripts can be explained by an aberrant splicing at the intron 1-exon 2 caused by the $\mathrm{T}$ nucleotide insertion. The sequence (CAGTTG) generated by $\mathrm{T}$ insertion in 'Pinalate' Z-ISO allele (Fig. 6a) highly resembles the intron 1-exon 2 junction (CAGGTTG) and might create a novel acceptor splice site skipping the first 42 nucleotides of exon 2.

The cDNA sequence data suggest that 'Pinalate' is heterozygous in the Z-ISO locus. This possibility was confirmed by direct sequencing genomic DNA of Z-ISO from 'Pinalate'. The nucleotide sequencing trace up to the $\mathrm{T}$ insertion site was unblemished indicating that is identical in both alleles. From the $\mathrm{T}$ insertion and on, the sequence trace became blurred due to a frameshift in one allele (Additional file 3: Figure S3).

\section{The Z-ISO encodes a bona fide 15-cis- $\zeta$-carotene isomerase but mutant variants ( $P 5$ and $P 6)$ are not functional}

The 15-cis- $\zeta$-carotene isomerization activity of Z-ISO variants was tested in E. coli cells carrying the pZETA vector that produced 9,15,9'tri-cis- $\zeta$-carotene. To that end, the full-length cDNAs of Z-ISO isolated from wild-type 'Navelate' (WT) and 'Pinalate' mutant, (variants P5 and P6) were cloned in the plasmid vector pGEM-T. E. coli cells carrying pZETA alone (control), pZETA together with WT or mutant Z-ISO cDNAs, were selected following transfection to $E$. coli cells and selection with the appropriate antibiotics. Carotenoid composition in the bacteria grown in suspension cultures was analyzed following incubation in dark or light conditions. E. coli cells with pZETA produced 9, 


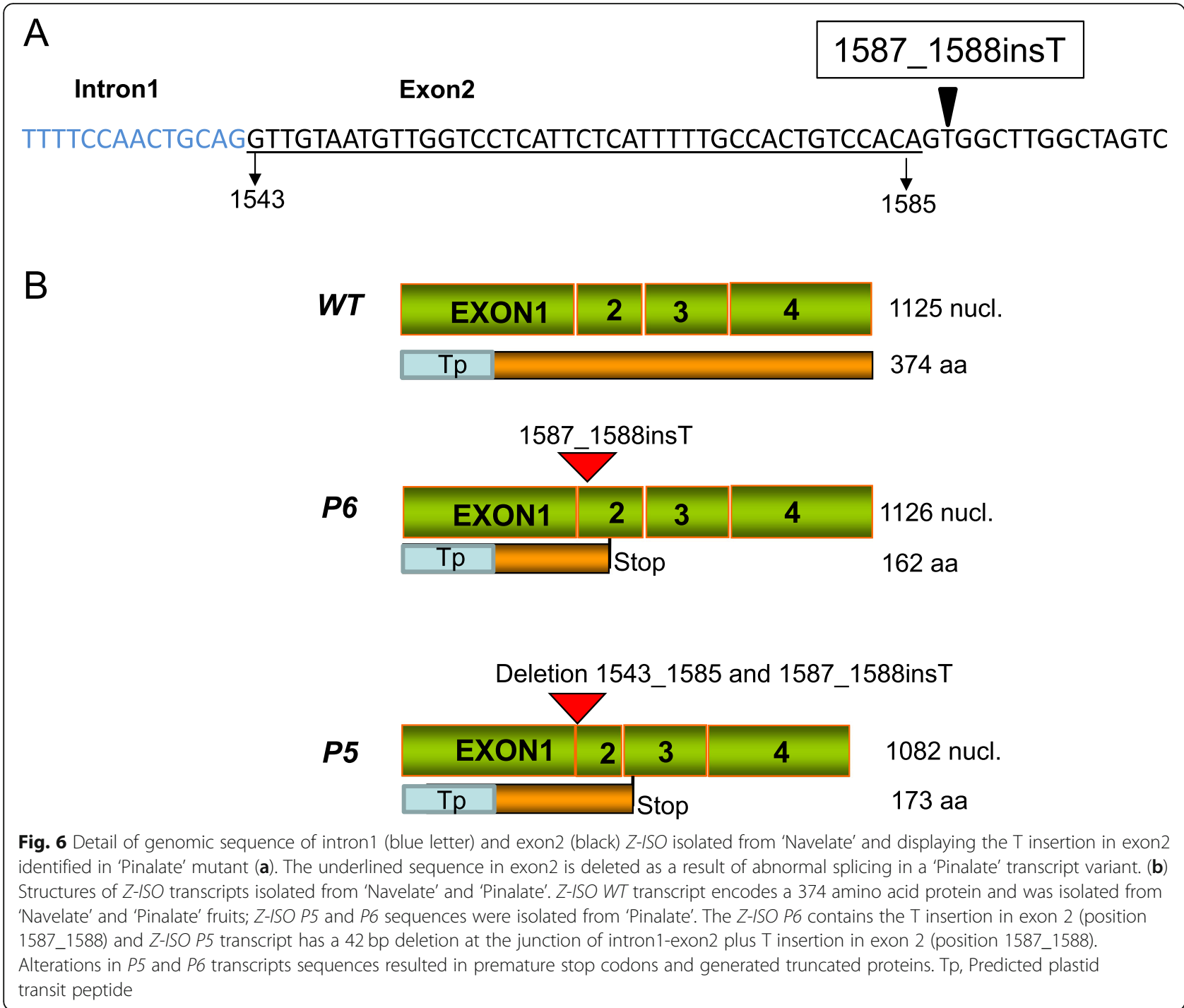

15,9'tri-cis- $\zeta$-carotene and 9,9'di-cis- $\zeta$-carotene at a ratio of $1: 2$, respectively (Fig. 7). In the presence of wild-type Z-ISO this ratio was changed to 1:1, but the mutant Z-ISO (P5 or P6) was inactive. Similar results were obtained when Z-ISO cDNAs from 'Pinalate' (P5 or P6) and 'Navelate' were expressed in E. coli with the plasmid pPROLYCOPENE (Additional file 4: Figure S4). These results demonstrate that citrus Z-ISO codes for a bona fide 15-cis- $\zeta$-carotene isomerase and both cDNA variants from 'Pinalate' abolished Z-ISO activity.

The presence of di-cis- $\zeta$-carotene in E. coli with pZETA alone may have resulted from a spontaneous chemical isomerization of the 15-cis double bond. This possibility is supported by the finding that when the $E$. coli cell cultures were exposed to dim white light $\left(50 \mu \mathrm{mol}\right.$ photons $\left.\mathrm{m}^{-2} \mathrm{~s}^{-1}\right)$, the non-enzymatic conversion of tri-cis to di-cis- $\zeta$-carotene increased even more than the enzymatic process (Fig. 7a, b).
However, conversion of tri-cis to di-cis with P5 and P6 mutant gene products in dark conditions was similar to empty vector pZETA, indicating no Z-ISO function for P5 and P6 while the functionality of WT Z-ISO sequence was demonstrated by a $25 \%$ increase in the proportion of di-cis-ל-carotene (Fig. 7a).

Expression level of Z-ISO is significantly down-regulated in 'Pinalate' mutant

The expression of Z-ISO gene was analyzed during fruit ripening and in young leaves from parental 'Navelate' and mutant 'Pinalate'. In parental fruit tissues a significant up-regulation in Z-ISO expression occurred during ripening, more noticeable in flavedo than in pulp (Fig. 8). In 'Navelate' ripe fruit compared to immature stage, the expression of Z-ISO was almost 8 and 3-fold higher in flavedo and pulp, respectively (Fig. 8). By contrast, the $Z$-ISO expression only exhibited a moderate increase in 

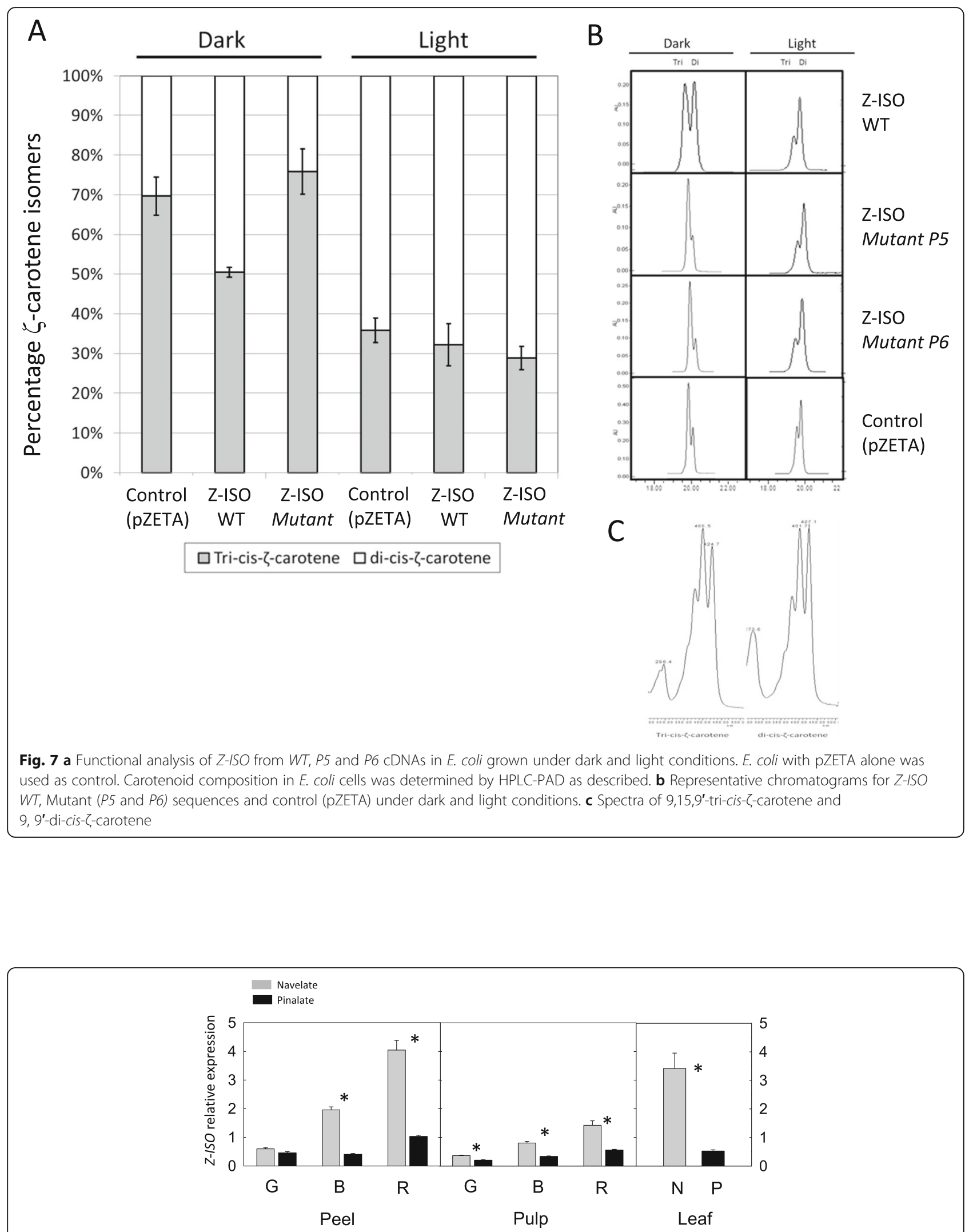

Fig. 8 Expression of Z-ISO gene in 'Navelate' (grey bars, N) and 'Pinalate' mutant (black bars, P) in peel and pulp from fruits at green (G), breaker (B) and full ripe (R) stage, and in young leaves. Asterisks indicate significant differences between 'Navelate' and 'Pinalate' samples ( $p \leq 0.01$ ) 
'Pinalate' fruit tissues during ripening. As a result, in mutant flavedo, pulp and leaves the Z-ISO expression was 3.8-, 2.5- and 5-fold lower than in wild-type, respectively, and only immature green peel of 'Pinalate' showed similar expression than parental (Fig. 8).

\section{Discussion}

The coloration of sweet orange is due to the carotenoid complement and is one of the main quality attributes with a major impact in consumers' acceptance. In addition, carotenoids in the flesh influence nutritional and health-related properties associated with sweet orange intake [1]. Research on carotenoid metabolism in citrus fruit has been an active field and most of the structural enzymes involved in the biosynthetic pathway have been functionally characterized [8-10, 21].

The 'Pinalate' sweet orange was originally identified as a bud mutant from 'Navelate' in a commercial orchard in San Pedro del Pinatar (Murcia, Spain) by the distinctive yellow coloration of mature fruit [38]. This phenotype was later associated with an elevated proportion of colorless carotenes and $\zeta$-carotene, and reduced downstream $\beta, \beta$-xanthophylls $[38,39]$. It is interesting to remark that the concentration of phytoene and phytofluene in 'Pinalate' is one of the highest reported among fruits [39, 45]. These carotenes are currently used as nutraceuticals ingredients and in cosmetic products, and their intake has been associated with beneficial effects on human health due to their antioxidant properties and the capacity to reduce the risk of certain cancers (reviewed in [50,51]). Therefore, understanding the molecular basis of 'Pinalate' phenotype may not only provide new clues on critical regulatory steps of carotenoid pathway in Citrus, but also valuable information to be used in breeding programs to enhance the content of phytoene and phytofluene in fruits. The carotenoid composition in 'Pinalate' fruit suggests that the alteration in the mutant is not associated to the ripening process, as the anomalous carotenoid profile is already manifested from early stages of fruit development (Fig. 2). Moreover, the carotenoid content in leaves also points that 'Pinalate' alteration is not restricted to fruit, as was previously proposed [38], since total carotenoids and chlorophylls are substantially reduced in leaves (Fig. 2c). Interestingly, similarly to leaves, green flavedo of 'Pinalate' shows reduced carotenoid content (Fig. 2a), which indicates a differential effect of the mutation in chloro- and chromoplasts. This contrasting effect on the carotenoid content in chloroplastic and non-chloroplastic tissues is not unexpected since the regulation and interaction of the carotenoid biosynthetic enzymes depends on plastid type and carotenoids fate in the tissue $[7,52,53]$.

Previous works in 'Pinalate' proposed a partial blockage in the carotenoid pathway at the level of $\zeta$-carotene desaturation $[38,39,45]$. However, the accumulation of the atypical $9,15,9^{\prime}$-tri-cis- $\zeta$-carotene isomer, not previously reported in other citrus fruit, and the absence of neurosporene, that accumulates in ZDS mutants of other plants [33], suggested a defect in Z-ISO, isomerase which catalyzes the cis-trans conversion of 15-15'double bond of 9,15,9'-tricis- $\zeta$-carotene [26, 27, 32], rather than in ZDS. The role of Z-ISO in fruits has been only explored in tomato by VIGSsilencing approach [33] or by characterization of defective tomato mutants (EU FPS DISCO Report https://cordis.europa.eu/project/rcn/110947/reporting/en). In $z$-iso tomato mutants the predominant carotenoid is phytoene $(32 \%$ of the total content), followed by phytofluene (16\%) and $\zeta$ carotene (13\%), and the ratio tri-cis:di-cis is approximately 0.5 [33]. This carotenoid composition resembles very closely that found in 'Pinalate' fruit (Figs. 2 and 3).

Light can partially mediate a spontaneous conversion of

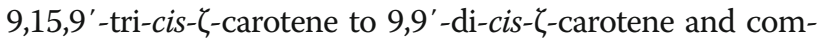
pensates the alterations in Z-ISO activity [26, 32, 33]. By visual field observations, it was noticed that peel areas of 'Pinalate' fruit directly exposed to sunlight developed a light-orange pigmentation in which the proportion of $\beta, \beta$ xanthophylls increased up to $16 \%$ (Fig. 3). By contrast, when 'Pinalate' fruits were prevented from light the proportion of $\beta, \beta$-xanthophylls was reduced to $1 \%$ (Fig. 3). More interestingly, the tri-cis:di-cis ratio was 2 -fold higher in dark- than in light-grown 'Pinalate' fruit. All these evidences are in full agreement with those observed in Z-ISOsilenced tomato fruit [33]. The phenotype of photosynthetic tissues grown under normal light conditions is less evident and light-exposed leaves of Z-ISO mutants only showed a reduced content of carotenoids and chlorophylls associated to pale-green coloration [26, 54]. A similar phenotype was also observed in 'Pinalate' young leaves, without other significant effects (Fig. 2c).

The comparative analysis of the transcriptional profiles of the main carotenoid biosynthetic genes in 'Pinalate' and 'Navelate' also suggest that alterations in Z-ISO may be responsible for the mutant phenotype (Figs. 4 and 8). In 'Pinalate', as in the parental fruit, the characteristic up-regulation of PSY, ZDS1, $\beta L C Y 2$ and $\beta C H X$ genes was associated with the induction of carotenogenesis [11-14], but only in the parental genotype the PSY transcript levels correlated well with total carotenoid content $[4,55]$. In 'Pinalate' flavedo, in contrast with the high content of phytoene at ripe stage, the expression of $P S Y$ was significantly lower than in the parental (Fig. 4), suggesting a negative feedback regulation of PSY. A similar effect was described in knockout $p d s$ Arabidopsis mutants where the early disruption of the pathway provokes accumulation of phytoene associated with down-regulation of $P S Y$ and $L C Y$ [56]. In the pulp, consistent with the lower carotenoid accumulation in this tissue, the relative expression level for all genes was lower than in flavedo $[8,12,13]$, and no significant differences in 
transcript accumulation were detected between both genotypes (Fig. 4). The alterations in gene expression detected in 'Pinalate' do not explain per se the abnormal carotenoid profile in the mutant. The biochemical and physiological data strongly suggested a defective Z-ISO in 'Pinalate', and analysis of the Z-ISO expression resulted in clear differences between mutant and parental genotypes. In 'Navelate' fruit Z-ISO followed an up-regulated pattern, similar and coordinated with other carotenoid biosynthetic genes, while in 'Pinalate' transcript levels of Z-ISO were significantly reduced and only a moderate increment was detected in ripe fruit (Figs. 3 and 8). In tomato, Z-ISO, together with $P S Y 1$, is one of the most strongly up-regulated genes during fruit ripening, increasing transcript abundance more than 33- and 20-fold from mature green to breaker and ripe stage, respectively [33, Sol Genomics Network expression database http://tea.solgenomics. net/expression_viewer/output gene Solyc12g098710].

It is remarkable that in 'Navelate' leaves the Z-ISO expression was as high as in ripe flavedo, suggesting an important role of this enzyme in the biosynthesis of carotenoids in chloroplasts, likely involved in carotenoid biosynthesis modulation under stress conditions [26].

As in other plants, Z-ISO is found in the sweet orange genome as single-copy gene showing a well conserved structure (Fig. 5). Modelling the sweet orange Z-ISO predicted an integral membrane protein with seven transmembrane domains and the three residues, H158, C271 and H274, were located in the 3D model in positions compatible with the proposed mechanism of ligand heme rearrangement [27]. The functionality of the sweet orange Z-ISO was confirmed by heterologous expression in E.coli (Fig. 7).

The genomic sequence of 'Pinalate' Z-ISO revealed a single $\mathrm{T}$ insertion at exon 2 , resulting in the generation of three different Z-ISO transcripts (Fig. 6). Since the sequencing showed that the mutation is in heterozygosity (Additional file 3: Figure S3), it was expected the WT transcript in 'Pinalate', but two more additional sequences, so-called $P 6$ and $P 5$, encoding truncated Z-ISO proteins with no activity in in vitro assays, were identified (Figs. 6 and 7). In line with previous studies, shorter Z-ISO transcripts with one less transmembrane domain encoded a non-functional protein, suggesting that this part of the protein is essential for the isomerase activity [27]. The 1:1 proportion of WT and altered (P5 and P6) sequences in 'Pinalate' also agrees with the heterozygous nature of the mutation (Additional file 3: Figure S3). In view of this situation, explaining of the phenotype of 'Pinalate' is not straightforward because null mutations in Z-ISO in other species are recessive [26, 32]. The cDNA data indicated that the $W T$ allele is transcribed in 'Pinalate' and comprises about half of Z-ISO transcripts.
Therefore, 'Pinalate' displays a definite phenotype expected from a lesion in Z-ISO with some leakiness that is manifested by synthesis of xanthophylls. A possible explanation could be dominant-negative effects by truncated Z-ISO polypeptides that interfere with the functioning of the $W T$ protein. Moreover, the reduced transcript level of Z-ISO in 'Pinalate' may be explained by a nonsense-mediated mRNA decay mechanism, which detects and rapidly degrades transcripts containing premature termination codons as reported for CRTISO gene in tomato tangerine $e^{3002}$ mutant [57].

One interesting feature is that the predominant carotenoid in 'Pinalate' mutant is phytoene, product of PSY activity, instead of the tri-cis- $\zeta$-carotene isomer, the substrate of Z-ISO. This proportion of carotenes fits with the model of three metabolic units proposed by Fantini et al. (2013) [33] in tomato. In this model, PDS and ZISO are part of a functional unit and a defect in one of the components, as in this case Z-ISO, would result in the preferential accumulation of phytoene, the substrate of the unit. Therefore, although carotenoid composition in ripe sweet orange fruit is very different to that found in tomato, the biosynthesis of carotenoids in chromoplasts of both species seems to share common regulatory mechanisms and similar structural organization of the early steps in multi-enzymatic complexes.

\section{Conclusions}

The yellow pigmentation of the sweet orange mutant 'Pinalate' is due to a reduction in $\beta, \beta$-xanthophylls and derived apocarotenoids. Analysis of carotenoid composition in fruit tissues identified the presence of six different $\zeta$-carotene isomers in 'Pinalate', including the 9,15, 9 '-tri- cis- $\zeta$-carotene, which was not previously reported in other citrus fruits. The dynamic changes in carotenoid profile in 'Pinalate' fruit tissues during ripening strongly suggests an impairment in Z-ISO activity, a recently discovered 15-cis-isomerase involved in the transformation of 9,15,9'-tri- cis- $\zeta$-carotene to 9,9'-di-cis- $\zeta$-carotene. The transcriptional analysis of main carotenoid biosynthetic showed no significant differences between 'Pinalate' and 'Navelate' genotypes that explain the mutant phenotype. Functional assays indicate that Z-ISO gene from sweet orange encodes a bona fide 15-cis-isomerase. The isolation of 'Pinalate' Z-ISO genomic sequence revealed a single nucleotide insertion in Z-ISO exon 2 in heterozygosis. This point mutation results in two additional alternative transcripts with a premature stop codons and non-functional proteins. The wild-type transcript version was also identified in 'Pinalate' fruit but a nonsense-mediated mRNA decay mechanism seems to operate since the expression of Z-ISO in 'Pinalate' is highly down-regulated compared to the parental. Remarkably, the effect of the mutation is less evident in 
chloroplastic tissues, suggesting that the role of this activity can be partially dispensable in photosynthetic tissues. In summary, the molecular basis of the altered carotenoid biosynthesis in the yellow 'Pinalate' sweet orange mutant has been identified as a single nucleotide insertion in Z-ISO gene, producing a massive accumulation of early upstream carotenes and revealing the crucial role of this activity in citrus carotenogenesis and fruit pigmentation.

\section{Methods}

\section{Plant material and treatments}

Plant material used for the experiments was collected from adult trees of sweet orange (Citrus sinensis L. Osbeck) cv. 'Navelate' and 'Pinalate' from the Citrus Germplasm Bank grown at Instituto Valenciano de Investigaciones Agrarias (Moncada, Valencia, Spain) (http://www.ivia.gva.es/es/banco-de-germoplasma-de-

citricos) [38]. Twenty Peel and pulp tissue from at least 15 fruits was collected at three developmental stages: immature green, harvested in July between 90 and 100 DAA (days after anthesis); breaker, harvested in October between 170 and 180 DAA; ripe, harvested in January between 280 and 300 DAA (Fig. 2). Fruits were selected for color and size uniformity, and absence of any lesion or injury. Immediately after harvest, flavedo tissue (outer and colored peel layer of the fruit) was collected with a scalpel carefully separating it from the albedo (white spongy mesocarp), and pulp juice vesicles were excised from central segments. Fully expanded young leaves (less than four months old) from the same orange trees were also collected. All the plant material was immediately frozen in liquid nitrogen, ground to a fine powder and stored at $-80^{\circ} \mathrm{C}$ until analysis.

To explore the effect of light on carotenoid composition in 'Pinalate' fruit peel, immature green fruits (July) were covered (dark grown) with black plastic bags with end-bottom open to allow gas exchange [46] and harvested in December. For comparison, non-covered 'Pinalate' fruits (light grown) were harvested in the same date. To maximize the effect of light exposure light grown fruits were chosen from the external canopy of the tree that was oriented towards the South which is the sunniest side. Two replicates consisting of 15 fruits were harvested from covered (dark growing conditions) and (light growing conditions) oranges and flavedo tissue was collected and stored as described above.

\section{Carotenoid extraction and quantification from fruit tissues and leaf}

Carotenoids from flavedo, pulp and leaf tissues were extracted as previously described [38, 39] with slight modifications. Briefly, freeze ground material of flavedo $(0.5 \mathrm{~g})$, pulp ( $2 \mathrm{~g})$ or leaf $(0.25 \mathrm{~g})$ was extracted essentially as previously described [14]. The carotenoid extracts were analyzed by HPLC in a Waters 600E pump and 2998 photodiode array detector (PAD) as described [18]. Carotenoid pigments were separated by HPLC using a $\mathrm{C}_{30}$ carotenoid column $(250 \times 4.6 \mathrm{~mm}, 5 \mu \mathrm{m})$ coupled to a $\mathrm{C}_{30}$ guard column $(20 \times 4.0 \mathrm{~mm}, 5 \mu \mathrm{m}$; YMC, Teknochroma, Spain) with ternary gradient elution of $\mathrm{MeOH}$, water and methyl tert-butyl ether [58]. Carotenoids were identified by their retention time, absorption and fine spectra [26, 33, 59, 60]. For each elution a Maxplot chromatogram was obtained and carotenoid contents were calculated using calibration curves of zeaxanthin (Extrasynthese), $\beta$-carotene (Sigma) for $\alpha$ - and $\beta$-carotene, $\beta$ cryptoxanthin (Extrasynthese), lutein (Sigma), antheraxanthin (CaroteNature), violaxanthin (CaroteNature) for violaxanthin and neoxanthin isomers, and $\beta$-apo- 8 '-carotenal (Extrasynthese) for $\beta$-citraurin. Phytoene, phytofluene and $\zeta$-carotene were previously purified as described [61] by thin layer chromatography from carotenoid extracts of 'Pinalate' orange fruit and the corresponding calibration curves performed [39]. The concentration of individual carotenoids are expressed as micrograms per $g$ of sample on fresh weight basis $\left(\mu \mathrm{g} \mathrm{g}^{-1} \mathrm{FW}\right)$.

Samples were extracted at least twice and each analytical determination was replicated. All operations were carried out on ice under dim light to prevent photodegradation, isomerisation and structural changes of carotenoids.

\section{Isolation of genomic and CDNA sequences of the Z-ISO gene in 'Navelate' wild-type and 'Pinalate' mutant}

Genomic DNA from immature fruits and leaves of C. sinensis 'Navelate' (wild-type cultivar) and 'Pinalate' (mutant) was isolated using DNeasy Plant Mini Kit (Qiagen) and was used to amplify the Z-ISO genomic sequences from both genotypes by PCR. The amplification was carried out using the primers MJ302F (5' - ATGAGCAGCAGTAGTTGTCTTC TTCTC-3') and MJ415R (5'- GCTTCTTTAATTCA AAGTTTGGGTTGCTTC-3') designed based on the orange1.1g017272m.g gene sequence (www.phytozome.com), and AccuPrime ${ }^{\mathrm{m}} \mathrm{Taq}$ DNA Polymerase High Fidelity (Invitrogen). The cycling program consisted of $2 \mathrm{~min}$ at $94^{\circ} \mathrm{C}$, then 35 cycles of $15 \mathrm{~s}$ at $94^{\circ} \mathrm{C}$ for denaturation, $30 \mathrm{~s}$ at $57^{\circ} \mathrm{C}$ for annealing and $3 \mathrm{~min}$ at $68^{\circ} \mathrm{C}$ for extension. The RNA isolation and cDNA synthesis from flavedo, pulp and leaf tissues were performed essentially as described in [62]. Briefly, total RNA was isolated by using RNeasy Plant Mini Kit (Qiagen) and subsequently treated with DNase I (DNA free, DNase treatment and removal, Ambion). The transcripts present in $5 \mu \mathrm{g}$ of total RNA were reversetranscribed using the Superscript III reverse transcriptase (Invitrogen) in a total volume of $20 \mu \mathrm{L}$. One $\mu \mathrm{L}$ of a tenfold diluted first-strand cDNA was used for the amplification of 
Z-ISO cDNA by PCR. The cycling program consisted of 2 min at $94{ }^{\circ} \mathrm{C}$, then 35 cycles of $15 \mathrm{~s}$ at $94^{\circ} \mathrm{C}$ for denaturation, $30 \mathrm{~s}$ at $57^{\circ} \mathrm{C}$ for annealing and $1 \mathrm{~min}$ at $68^{\circ} \mathrm{C}$ for extension. Two independent cloning experiments were carried out using PCR products amplified from the cDNA of the peel and pulp of 'Navelate' and 'Pinalate' at breaker stage, and the genomic DNA from immature green fruits and leaves. The fragments were cloned into $\mathrm{PGEM}^{\circ}-\mathrm{T}$ (Promega Corporation, Madison, WI, USA) and at least 10 or 71 independent clones were sequenced per genotype for the genomic or cDNA amplification, respectively.

\section{Functional analysis of Citrus Z-ISO in Escherichia coli}

Full length cDNAs of Z-ISO isolated from 'Navelate' and 'Pinalate' were cloned in the plasmid vector pGEM $^{\circ}-\mathrm{T}$ (Promega Corporation, Madison, WI, USA). These plasmids were transfected into E. coli strain XL1-Blue carrying the $\zeta$-carotene-producing plasmid pZETA, which carries the genes crtB and $c r t E$ from Pantoea agglomerans and crtP from the cyanobacterium Synechococcus elongatus PCC7942 in the plasmid vector pACYC184, or the prolycopene-producing pPROLYCOPENE [63]. Cells of $E$. coli carrying pZETA or pPROLYCOPENE vectors alone served as a control.

Two millilitres of overnight suspension culture of $E$. coli cells were inoculated into $100 \mathrm{~mL}$ of Luria-Bertani medium in a $500 \mathrm{~mL}$ flask with antibiotics chloramphenicol $\left(34 \mathrm{mg} \mathrm{L}^{-1}\right)$ and ampicillin $\left(50 \mathrm{mg} \mathrm{L}^{-1}\right)$. Cells were cultured for $8 \mathrm{~h}$ at $37^{\circ} \mathrm{C}$ in the dark and then induced with $10 \mathrm{mM}$ isopropylthio- $\beta$-galactoside, followed by $40 \mathrm{~h}$ of slow shaking $(100 \mathrm{rpm})$ at room temperature and an additional 2 day without shaking prior to carotenoid extraction. Bacterial cells were collected by centrifugation and the pellet was extracted in acetone until loss of color. The acetone extracts were dried under a stream of $\mathrm{N}_{2}$ and re-dissolved in $500 \mu \mathrm{l}$ acetone for HPLC analysis.

For testing the effect of light, flasks were covered with aluminum foil; otherwise the light intensity was ca. 50 $\mu \mathrm{E} \mathrm{m}^{-2} \mathrm{~s}^{-1}$. Carotenoids were analyzed by HPLC using a Waters system consisting of Waters 600 pump, Waters 996 PAD and Waters 717 plus Autosampler as previously describe [64].

\section{Gene expression analysis}

Gene expression analyses were performed following the Minimum Information for publication of Quantitative real-time PCR Experiments (MIQE) guidelines [65]. Quantitative real-time PCR was carried out on a LightCycler 480 instrument (Roche) following conditions described in [66]. The RNA isolation and cDNA synthesis from flavedo, pulp and leaf tissues were performed essentially as described in [62] and mentioned above in the section entitled isolation of genomic and cDNA. The absence of DNA contamination was checked in all samples by performing a no-reverse transcription assay which consisted of a PCR with each RNA sample using the citrus ACTIN primers The primers employed for the amplification of the PSY, PDS, $\beta L C Y 1, \beta L C Y 2, \beta C H X$, $Z E P$ were described in [58], for ZDS1, ZDS2, ZDS3 in [46] and for Z-ISO were MJ283F (sense, 5'-GCAGCG TCACTGGGTTTAAT-3') and MJ284R (antisense, 5'GTTCGCCTCTTCACAGCTTC-3') which amplify a region in the exon 4 . The cycling protocol conditions used for all genes are essentially as described previously in [67]. The calculated expression levels were relative to values of an external reference sample (flavedo from 'Navelate' fruit at mature green stage harvested in September) using the Relative Expression Software Tool [68]. Normalization was performed using the expression levels of the ACTIN gene [62]. Results were the average of 4 independent replicates.

To test for significant differences on transcript levels between samples, a pair-wise fixed reallocation randomization test was applied $(P \leq 0.01)[68]$.

\section{Supplementary information}

Supplementary information accompanies this paper at https://doi.org/10. 1186/s12870-019-2078-2.

Additional file 1: Figure S1. Spectra of $\zeta$-carotene isomers identified in chromatograms of 'Pinalate' carotenoid extracts. Z1, 9,15,9'-tri-cis-Z-caro-

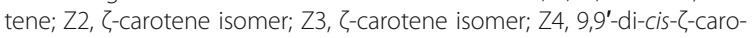
tene; Z5, Z-carotene isomer; Z6, Z-carotene isomer.

Additional file 2: Figure S2. Representative MaxPlots chromatograms obtained from pulp carotenoids extracts of 'Navelate' (parental) and 'Pinalate' (mutant).; U1, unknown (wavelength absorbance spectrum: 401,416,446); U2, unknown (426,450); U3, unkown (320,356,377); N, Neochrome; Nx, neoxanthin; V1, all-trans-violaxanthin; V2, 9-cisviolaxanthin; L, lutein; Zx, zeaxanthin; $A$, antheraxanthin;P1, 15-cisPhytoene; Pf1, Phytofluene isomer; Pf2, Phytofluene isomer2; Cx, $\beta$ -

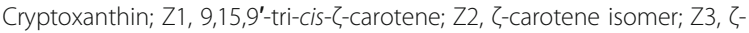

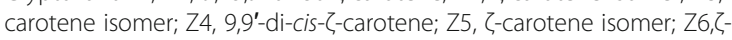
carotene isomer; $B C, \beta$-carotene.

Additional file 3: Figure S3. Direct sequencing of Z-ISO genomic DNA from 'Pinalate' amplified by PCR. The nucleotide sequencing with a reverse primer in Z-1SO trace up to the $T$ insertion site (indicated with an *) showing identical sequence between WT and 'Pinalate' alleles (bold letters). From the $T$ insertion and on, the sequence trace became blurred in 'Pinalate' genomic due to a frameshift in one allele.

Additional file 4: Figure S4. Functional analysis of citrus Z-ISO in E.coli PPROLYCOPENE strain. Carotenes composition in extracts from E. coli with PPROLYCOPENE plasmid and C Z-ISO from 'Navelate or 'Pinalate' (mutant) P5 and P6 cDNAs. E. coli with PPROLYCOPENE alone was used as control. Carotenoid analysis in E. coli cells was determined by HPLC-PAD as described in Material and Methods section.

\section{Abbreviations}

ABA: Abscisic acid; DAA: Days after anthesis; FW: Fresh weight; PDS: Phytoene desaturase; PSY: Phytoene synthase; ZDS: Z-carotene desaturase; Z-ISO: 15-cis-Z-carotene isomerase; $\beta$ CHX: Non-heme $\beta$-carotene hydroxylase; $\beta L C Y 1$ : Lycopene $\beta$-cyclase 1; $\beta L C Y 2$ : Chromoplast-specific lycopene $\beta$-cyclase2; $\varepsilon L C Y$ : Lycopene $\varepsilon$-cyclase 


\section{Acknowledgements}

The authors would like to thank Amparo Beneyto and Inmaculada Carbonell for their technical assistance in the carotenoid analysis, Dr. J.F. Marcos for fruitful and valuable discussions in this project, and Dr. G. Ancillo and A. Medina for the use of Citrus Germplasm Bank at IVIA (Moncada, Valencia, Spain).

\section{Authors' contributions}

MJR conceived the experimental design, interpretation of data and wrote the manuscript; $J$, performed field experiments, carotenoid analysis and gene expression analysis; EA, performed gene expression and cloned Z-ISO gene; $B A$, participate in gene expression analysis; $O D$, carried out functional analysis of Z-ISO; JH, participate in functional analysis of Z-ISO, sequencing Z$1 S O$ and interpretation of the data; $L Z$, participate in experimental design, interpretation of data and reviewed the manuscript. All authors have read and approved the manuscript.

\section{Funding}

Financial support of the research grants AGL2012-34576 and AGL201570218 (Ministerio Economía y Competitividad, Spain), and RTI2018-095131-B100 (Ministerio Ciencia, Innovacion y Universidades, Spain). Work in the group of JH was supported by Israel Science Foundation Grant 850/13. MJR, LZ, JH and OD are members of Eurocaroten (COST_Action CA15136). MJR and LZ belong to CaRed (Spanish Carotenoid Network BIO2017-90877-REDT, Ministerio de Ciencia, Innovación y Universidades, Spain). Authors acknowledge support of the publication fee by the CSIC Open Access Publication Support Initiative through its Unit of Information Resources for Research (URICI).

\section{Availability of data and materials}

All data supporting the findings is contained in the manuscript and its supplementary files.

\section{Ethics approval and consent to participate}

Not applicable.

\section{Consent for publication}

Not applicable.

\section{Competing interests}

The authors declare that this research was conducted in the absence of any commercial or financial relationships that could be construed as a potential competing interest.

\section{Author details}

'Instituto de Agroquímica y Tecnología de Alimentos (IATA), Consejo Superior de Investigaciones Científicas (CSIC), Calle Catedrático Agustín Escardino 7, 46980 Valencia, Spain. ${ }^{2}$ Instituto Nacional de Investigación Agropecuaria (INIA), Salto, Uruguay. Instituto de Biología Molecular y Celular de Plantas (IBMCP) UPV-CSIC, Valencia, Spain. ${ }^{4}$ Alexander Silberman Institute of Life Sciences, The Hebrew University of Jerusalem, Jerusalem, Israel.

\section{Received: 17 June 2019 Accepted: 16 October 2019}

\section{Published online: 04 November 2019}

\section{References}

1. Lado J, Gambetta G, Zacarias L. Key determinants of citrus fruit quality: metabolites and main changes during maturation. Sci Hortic. 2018;233: 238-48.

2. Yabuzaki J. Carotenoids Database: structures, chemical fingerprints and distribution among organisms. Database: the journal of biological datbases and curation. 2017;2017(1):bax004. https://doi.org/10.1093/database/bax004.

3. Britton G, Liaaen-Jensen S, Pfander H. Carotenoids Handbook. Publ. Ed, vol. 1. Basel: Birkhäuser Basel; 2004.

4. Rodriguez-Concepcion M, Avalos J, Luisa Bonet M, Boronat A, GomezGomez L, Hornero-Mendez D, Limon MC, Meléndez-Martínez AJ, OlmedillaAlonso B, Palou A, Ribo J, Rodrigo MJ, Zacarias L, Zhu C. A global perspective on carotenoids: metabolism, biotechnology, and benefits for nutrition and health. Prog Lipid Res. 2018;70:62-93.

5. Enfissi EMA, Nogueira M, Bramley PM, Fraser PD. The regulation of carotenoid formation in tomato fruit. Plant J. 2017;89:774-88.
6. Nisar N, Li L, Lu S, Khin NC, Pogson BJ. Carotenoid metabolism in plants. Mol Plant. 2015;8(1):68-82.

7. Shumskaya M, Wurtzel ET. The carotenoid biosynthetic pathway: thinking in all dimensions. Plant Sci. 2013;208:58-63.

8. Rodrigo MJ, Alquézar B, Alós E, Lado J, Zacarías L. Biochemical bases and molecular regulation of pigmentation in the peel of Citrus fruit. Sci Hortic. 2013;163:42-62

9. Wei $\mathrm{X}, \mathrm{Hu} H$, Tong $\mathrm{H}$, Gmitter FG. Profiles of gene family members related to carotenoid accumulation in Citrus genus. J Plant Biol. 2017;60(1):1-10.

10. Ikoma Y, Matsumoto H, Kato M. Diversity in the carotenoid profiles and the expression of genes related to carotenoid accumulation among citrus genotypes. Breed Sci. 2016;66(1):139-47.

11. Rodrigo MJ, Marcos JF, Zacarías L. Biochemical and molecular analysis of carotenoid biosynthesis in flavedo of orange (Citrus sinensis L.) during fruit development and maturation. J Agric Food Chem. 2004;52(22):6724-31.

12. Kato M, Ikoma $Y$, Matsumoto $H$, Sugiura M, Hyodo $H$, Yano M. Accumulation of carotenoids and expression of carotenoid biosynthetic genes during maturation in citrus fruit. Plant Physiol. 2004;134(2):824-37.

13. Alquezar $B$, Rodrigo MJ, Zacarías L. Regulation of carotenoid biosynthesis during fruit maturation in the red-fleshed orange mutant Cara Cara. Phytochemistry. 2008;69(10):1997-2007.

14. Alquézar B, Zacarías L, Rodrigo MJ. Molecular and functional characterization of a novel chromoplast-specific lycopene $\beta$-cyclase from Citrus and its relation to lycopene accumulation. J Exp Bot. 2009;60(6):1783-97.

15. Fanciullino AL, Cercós M, Dhuique-Mayer C, Froelicher $Y$, Talón M, Ollitrault $P$, Morillon R. Changes in carotenoid content and biosynthetic gene expression in juice sacs of four orange varieties (Citrus sinensis) differing in flesh fruit color. J Agric Food Chem. 2008;56(10):3628-38.

16. Liu Q, Zhu A, Chai L, Zhou W, Yu K, Ding J, Xu J, Deng XX. Transcriptome analysis of a spontaneous mutant in sweet orange [Citrus sinensis ( $\mathrm{L}$.) Osbeck] during fruit development. J Exp Bot. 2009;60(3):801-13.

17. Wei X, Chen C, Yu Q, Gady A, Yu Y, Liang G, Gmitter F Jr. Novel expression patterns of carotenoid pathway-related genes in citrus leaves and maturing fruits. Tree Genet Genomes. 2014;10(3):439-48.

18. Rodrigo MJ, Alquézar B, Alós E, Medina V, Carmona L, Bruno M, AlBabili S, Zacarias L. A novel carotenoid cleavage activity involved in the biosynthesis of Citrus fruit-specific apocarotenoid pigments. J Exp Bot. 2013;64(14):4461-78.

19. Ma G, Zhang L, Matsuta A, Matsutani K, Yamawaki K, Yahata M, Wahyudi A, Motohashi R, Kato M. Enzymatic formation of $\beta$-citraurin from $\beta$-cryptoxanthin and zeaxanthin by carotenoid cleavage dioxygenase 4 in the flavedo of citrus fruit. Plant Physiol. 2013;163(2):682-95.

20. Melendez-Martinez AJ, Britton G, Vicario IM, Heredia FJ. The complex carotenoid pattern of orange juices from concentrate. Food Chem. 2008;109(3):546-53.

21. Kato M. Mechanism of carotenoid accumulation in citrus fruit. J Japan Soc Horticultural Sci. 2012;81(3):219-33.

22. Chen C, Lo Piero AR, Gmitter F Jr. Pigments in Citrus. In: Chen C, editor. Pigments in Fruits and Vegetables. New York: Springer; 2015. p. 165-88.

23. Liu Q, Xu J, Liu Y, Zhao X, Deng X, Guo L, Gu J. A novel bud mutation that confers abnormal patterns of lycopene accumulation in sweet orange fruit (Citrus sinensis L. Osbeck ). J Exp Bot. 2007:58(15):4161-71.

24. Wei X, Chen C, Yu Q, Gady A, Yu Y, Liang G, Gmitter F Jr. Comparison of carotenoid accumulation and biosynthetic gene expression between Valencia and Rohde red Valencia sweet oranges. Plant Sci. 2014;227:28-36.

25. Petry FC, de Nadai FB, Cristofani-Yaly M, Latado RR, Mercadante AZ. Carotenoid biosynthesis and quality characteristics of new hybrids between tangor (Citrus reticulata $\times$ C. sinensis) cv. 'Murcott' and sweet orange (C. sinensis) cv. 'Pera.'. Food Res Int. 2019;122:461-70.

26. Chen Y, Li F, Wurtzel ET. Isolation and characterization of the Z-ISO gene encoding a missing component of carotenoid biosynthesis in plants. Plant Physiol. 2010;153(1):66-79.

27. Beltrán J, Kloss B, Hosler JP, Geng J, Liu A, Modi A, Dawson JH, Sono M, Shumskaya M, Ampomah-Dwamena C, Love JD, Wurtzel ET. Control of carotenoid biosynthesis through a heme-based cis-trans isomerase. Nat Chem Biol. 2015;11:598-605.

28. Isaacson T, Ronen G, Zamir D, Hirschberg J. Cloning of tangerine from tomato reveals a carotenoid Isomerase essential for the production of bcarotene and Xanthophylls in plants. Plant Cell. 2002;14:333-42.

29. Yan F, Shi M, He Z, Wu L, Xu X, He M, Chen J, Deng X, Cheng Y, Xu J. Largely different carotenogenesis in two pummelo fruits with different flesh colors. PLoS One. 2018;13(7):e0200320. https://doi.org/10.1371/journal.pone.0200320. 
30. Zhang L, Ma G, Shirai Y, Kato M, Yamawaki K, Ikoma Y, Matsumoto $H$. Expression and functional analysis of two lycopene $\beta$-cyclases from citrus fruits. Planta. 2012;236(4):1315-25.

31. Ma G, Zhang L, Yungyuen W, Tsukamoto I, lijima N, Oikawa M, Yamawaki K, Yahata M, Kato M. Expression and functional analysis of citrus carotene hydroxylases: unravelling the xanthophyll biosynthesis in citrus fruits. BMC Plant Biol. 2016;16(1):148.

32. Li F, Murillo C, Wurtzel ET. Maize Y9 encodes a product essential for 15-ciscarotene isomerization. Plant Physiol. 2007;144(2):1181-9.

33. Fantini E, Falcone G, Frusciante S, Giliberto L, Giuliano G. Dissection of tomato lycopene biosynthesis through virus-induced gene silencing. Plant Physiol. 2013;163(2):986-98.

34. Zhang M, Deng XX. Advances in research of citrus cultivars selected by bud mutation and the mechanism of formation of mutated characteristics. J Fruit Sci. 2006;23:871-6.

35. Rodrigo MJ, Cilla A, Barbera R, Zacarias L. Carotenoid bioaccessibility in pulp and fresh juice from carotenoid-rich sweet oranges and mandarins. Food Funct. 2015;6(6):1950-9.

36. Lu P, Wang C, Yin T, Zhong S, Grierson D, Chen K, Xu C-J. Cytological and molecular characterization of carotenoid accumulation in normal and highlycopene mutant oranges. Sci Rep. 2017;7(1):761.

37. Xu Q, Yu K, Zhu A, Ye J, Liu Q, Zhang J, Deng XX. Comparative transcripts profiling reveals new insight into orange (Citrus sinensis) red-flesh mutant. BMC Genomics. 2009;15:1-15.

38. Rodrigo MJ, Marcos JF, Alferez F, Mallent M, Zacarias L. Characterization of 'Pinalate', a novel Citrus sinensis mutant with a fruit specific alteration that results in yellow pigmentation and decreased ABA content. J Exp Bot. 2003; 54:727-38.

39. Lado J, Zacarías L, Gurrea A, Page A, Stead A, Rodrigo MJ. Exploring the diversity in Citrus fruit colouration to decipher the relationship between plastid ultrastructure and carotenoid composition. Planta. 2015;242(3):645-61.

40. Romero P, Lafuente MT, Rodrigo MJ. The Citrus ABA signalosome: identification and transcriptional regulation during sweet orange fruit ripening and leaf dehydration. J Exp Bot. 2012;63(13):4931-45.

41. Alférez F, Sala JM, Sanchez-Ballesta MT, Mulas M, Lafuente MT, Zacarias L. A comparative study of the postharvest performance of an ABA-deficient mutant of oranges. Postharvest Biol Technol. 2005;37(3):222-31.

42. Romero P, Rodrigo MJ, Alferez F, Ballester AR, González-Candelas L, Zacarías $L$, Lafuente MT. Unravelling molecular responses to moderate dehydration in harvested fruit of sweet orange (Citrus sinensis $L$. Osbeck ) using a fruitspecific ABA-deficient mutant. J Exp Bot. 2012;63(7):2753-67.

43. Romero P, Rodrigo MJ, Lafuente MT. Differential expression of the Citrus sinensis ABA perception system genes during postharvest fruit dehydration. Postharvest Biol Technol. 2013:76:65-73.

44. Romero P, Lafuente MT, Alférez F. A transcriptional approach to unravel the connection between phospholipases $A_{2}$ and $D$ and $A B A$ signal in citrus under water stress. Plant Physiol Biochem. 2014;80:23-32.

45. Mapelli-Brahm P, Stinco CM, Rodrigo MJ, Zacarías L, Meléndez-Martínez AJ. Effect of thermal treatments in orange juice on the bioaccessibility of phytoene and phytofluene in relation to changes in particle size and in plastids. J Funct Foods. 2018;46:38-47.

46. Lado J, Cronje P, Alquézar B, Page A, Manzi M, Gómez-Cadenas A, Stead AD Zacarías L, Rodrigo MJ. Fruit shading enhances peel color, carotenes accumulation and chromoplast differentiation in red grapefruit. Physiol Plant. 2015;154(4):469-84

47. Roy A, Kucukural A, Zhang Y. I-TASSER: a unified platform for automated protein structure and function prediction. Nat Protoc. 2010;5(4):725-38.

48. Nugent T, Jones DT. Transmembrane protein topology prediction using support vector machines. BMC Bioinformatics. 2009:10:159.

49. Shimizu T, Tanizawa Y, Mochizuki T, Nagasaki H, Yoshioka T, Toyoda A, Fujiyama A, Kaminuma E, Nakamura Y. Draft sequencing of the heterozygous diploid genome of Satsuma (Citrus unshiu Marc.) using a hybrid assembly approach. Front Genet. 2017:8:1-19.

50. Meléndez-Martínez AJ, Mapelli-Brahm P, Stinco CM. The colourless carotenoids phytoene and phytofluene: from dietary sources to their usefulness for the functional foods and nutricosmetics industries. J Food Compos Anal. 2018;67:91-103.

51. Miras-Moreno B, Pedreño MA, Romero LA. Bioactivity and bioavailability of phytoene and strategies to improve its production. Phytochem Rev. 2019; 18:359-376.
52. Wurtzel ET. Changing form and function through carotenoids and synthetic biology. Plant Physiol. 2019;179(3):830-43 12:6.

53. Sun T, Yuan H, Cao H, Yazdani M, Tadmor Y, Li L. Carotenoid metabolism in plants: the role of plastids. Mol Plant. 2018;11:58-74.

54. Janick-Buckner D, O’Neal J, Joyce E, Buckner B. Genetic and biochemical analysis of the $y 9$ gene of maize, a carotenoid biosynthetic gene. Maydica. 2001:46:41-6.

55. Lado J, Zacarias L, Rodrigo MJ. Regulation of carotenoid biosynthesis during fruit development (Chapter 6). In: Carotenoids in Nature, Ed C. Stange. Springer International, Series Sub-Cellular Biochemistry 79; 2016 p. 161-198.

56. Qin G, Gu H, Ma L, Peng Y, Deng XW, Chen Z, Qu L-J. Disruption of phytoene desaturase gene results in albino and dwarf phenotypes in Arabidopsis by impairing chlorophyll, carotenoid and gibberellin biosynthesis. Cell Res. 2007;17(5):471-82.

57. Kachanovsky DE, Filler $\mathrm{S}$, Isaacson T, Hirschberg J. Epistasis in tomato color mutations involves regulation of phytoene synthase 1 expression by ciscarotenoids. Proc Natl Acad Sci U S A. 2012;109(46):19021-6.

58. Carmona L, Zacarías L, Rodrigo MJ. Stimulation of coloration and carotenoid biosynthesis during postharvest storage of 'Navelina' orange fruit at $12^{\circ} \mathrm{C}$. Postharvest Biol Technol. 2012;74:108-17.

59. Rouseff R, Raley L, Hofsommer HJ. Application of diode array detection with a C-30 reversed phase column for the separation and identification of saponified orange juice carotenoids. J Agric Food Chem. 1996;44:2176-81.

60. Breitenbach J, Sandmann G. Z-Carotene cis isomers as products and substrates in the plant poly-cis carotenoid biosynthetic pathway to lycopene. Planta. 2005;220(5):785-93.

61. Pascual M, Mallent MD, Cuñat P. Study of the 'Naveline' orange carotenoids. Revista de Agroquimica y Tecnologia de Alimentos. 1993;33:179-96.

62. Alós E, Rodrigo MJ, Zacarías L. Differential transcriptional regulation of Lascorbic acid content in peel and pulp of citrus fruits during development and maturation. Planta. 2014;239(5):1113-28.

63. Cunningham FX, Gantt E. A portfolio of plasmids for identification and analysis of carotenoid pathway enzymes: Adonis aestivalis as a case study. Photosynth Res. 2007;92(2):245-59.

64. Neuman H, Galpaz N, Cunningham FX, Zamir D, Hirschberg J. The tomato mutation nxd1 reveals a gene necessary for neoxanthin biosynthesis and demonstrates that violaxanthin is a sufficient precursor for abscisic acid biosynthesis. Plant J. 2014;78:80-93.

65. Bustin A, Benes V, Garson JA, Hellemansm J, Huggett J, Kubista M, Mueller R, Nolan T, Pfaffl MW, Shipley GL, Vandesompele J, Wittwer CT. The MIQE guidelines: minimum information for publication of quantitative real-time PCR experiments. Clin Chem. 2009;55:611-22.

66. Alos E, Martinez-Fuentes A, Reig C, Mesejo C, Zacarías L, Agustí M, Rodrigo MJ. Involvement of ethylene in color changes and carotenoid biosynthesis in loquat fruit (Eriobotrya japonica Lindl. CV. Algerie). Postharvest Biol Technol. 2019;149:129-38.

67. Lado J, Alós E, Rodrigo MJ, Zacarías L. Light avoidance reduces ascorbic acid accumulation in the peel of Citrus fruit. Plant Sci. 2015:231:138-47.

68. Pfaffl MW, Horgan GW, Dempfle L. Relative expression software tool (REST) for group-wise comparison and statistical analysis of relative expression results in real-time PCR. Nucleic Acid Res. 2002;30:e36.

\section{Publisher's Note}

Springer Nature remains neutral with regard to jurisdictional claims in published maps and institutional affiliations.

Ready to submit your research? Choose BMC and benefit from:

- fast, convenient online submission

- thorough peer review by experienced researchers in your field

- rapid publication on acceptance

- support for research data, including large and complex data types

- gold Open Access which fosters wider collaboration and increased citations

- maximum visibility for your research: over $100 \mathrm{M}$ website views per year

At $\mathrm{BMC}$, research is always in progress.

Learn more biomedcentral.com/submissions 